\title{
Extending operations research to social marketing programs
}

Teresa de Vargas

Follow this and additional works at: https://knowledgecommons.popcouncil.org/departments_sbsr-rh

Part of the Demography, Population, and Ecology Commons, Health Services Research Commons, and the International Public Health Commons

How does access to this work benefit you? Let us know!

\section{Recommended Citation}

de Vargas, Teresa. 2001. "Extending operations research to social marketing programs," FRONTIERS Final Report. Washington, DC: Population Council. 


\title{
Extending Operations Research to Social Marketing Programs
}

\author{
Teresa de Vargas \\ CEMOPLAF \\ Ecuador
}

December 2001

This project was funded by the U.S. AGENCY FOR INTERNATIONAL DEVELOPMENT (USAID) under the terms of Cooperative Agreement Number HRNA-00-98-00012-00 and Subagreement number AI99.29A. The opinions expressed herein are those of the authors and do not necessarily reflect the views of USAID. 


\section{SUMMARY}

A FRONTIERS objective is to extend operations research (OR) into new areas such as sustainability research and social marketing. This project marks a departure into these areas.

CEMOPLAF of Quito, Ecuador sells reproductive health products to pharmacies and other outlets to contribute to the sustainability of the not-for-profit agency. CEMOPLAF lacked basic information regarding the program's profitability, niche, and quality. OR to provide this information included a financial analysis of the marketing program and two market research studies. Each study included a capacity building component so that CEMOPLAF could conduct similar studies in the future without technical assistance. A regional conference attended by non-governmental organizations (NGOs) was also included. The conference objective was to share sustainability tools and lessons learned. The Commercial Market Strategies (CMS) project co-sponsored the conference.

Marketing Project Profitability Analysis: The study found that the marketing program was profitable during the calendar year 1998, generating \$103,000 in net profits. Return on sales revenue was 10 percent. The condom brand Protektor brought in the most revenue of any product, and contributed the highest total gross profits. Protektor's dominance was due to high sales volume, since the product is near to the bottom of the list of net revenue per unit sold. Half of the sales force was responsible for nearly all of the profits, and most of these agents worked in Quito-Guayaquil. Major recommendations implemented by CEMOPLAF included shifting from sales revenue to gross profit as an indicator of sales agent success, and a change from a salary-based compensation system to a more heavily commission-based compensation system for sales agents. Other important long-term impacts of this study include: (a) SM executives learned to use the tools introduced in this study to routinely analyze financial performance from a profitability perspective; and (b) sales agents now have access to information for tracking unit profit margins, trends in sales volume, and the financial performance of their own regions.

Marketing Project Client Profile: The study was conducted in a sample of pharmacies in five cities. Results indicate that purchasers of CEMOPLAF contraceptives are of lower socio-economic status than are purchasers of other contraceptive brands, and of purchasers of non-contraceptive products in the pharmacies studied. Information on nonCEMOPLAF products purchased by customers was also obtained from the study, as was information on products that were frequently sought but also frequently out of stock in the pharmacies. This data helped CEMOPLAF decide to market higher margin, nonreproductive health products (including those frequently out of stock) directed at the pharmacies' more affluent clients.

Quality of Information Provided to CEMOPLAF Customers: Mystery shoppers purchased CEMOPLAF oral contraceptives, DMPA and pregnancy tests from a representative sample of pharmacies. This study revealed that pharmacists behave very 
much like clinical providers of family planning methods; they provide clients with method use instructions, but little or no information about side effects and contraindications. However, information on these aspects of method use was increased when clients asked specific questions of the pharmacists. Due to lack of funds, the recommended intervention to increase information transfer - posters reminding clients to ask the provider about contraindications and side-effects - could not be implemented.

Capacity Building Activities: As a result of the financial analysis, CEMOPLAF marketing managers learned to gather and use profit data to make decisions regarding individual sales agents, specific products and overall program direction. FRONTIERS assistance also included three workshops for 28 program staff on market segmentation, sales techniques, and billing and receiving. A local expert taught each workshop.

CEMOPLAF research staff learned to conduct point of purchase surveys, mystery client studies, and financial analyses. Other agency staff gained experience as interviewers and mystery clients, leaving the agency with the infrastructure needed to conduct future market research.

Latin American Regional Conference on Sustainability and Social Mission: More than 80 individuals registered to attend the conference. They represented over 40 family planning organizations, research organizations, pharmaceutical companies, and donors. The conference objectives were to:

- Share sustainability research and lessons learned;

- Share experiences of NGOs that have attempted to improve the sustainability of programs while maintaining their commitment to social mission; and

- Provide NGOs and companies that market reproductive health products the opportunity to explore the possibility of commercial agreements.

Evaluation of the conference was positive, with almost 90 percent of participants rating it as "useful" or "very useful." CMS and FRONTIERS are in the process of planning a similar conference for Africa. 


\section{CONTENTS}

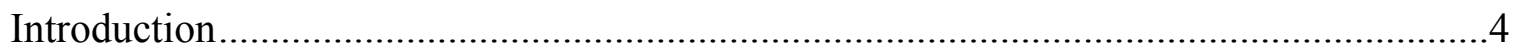

Study I: A Financial Analysis of the CEMOPLAF Social Marketing Program ...................5

Study II: Market Assessment for CEMOPLAF Products: Customer Profile .....................14

Study III: Quality of Care Issues in Delivery of Injectable and Oral Contraceptives and a Pregnancy Test in Ecuadorean Pharmacies................................................28

Conference: Sustainability and Social Mission: Sharing Lessons from

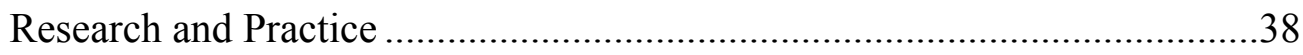

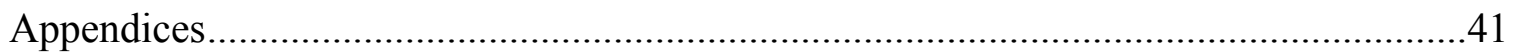




\section{INTRODUCTION}

Operations research (OR) has played an important role in all types of family planning and reproductive health service delivery modalities with the exception of social and commercial marketing programs where research has been limited mainly to market surveys. The current movement towards sustainability is causing social marketing (SM) programs to examine issues like profitability, productivity and quality. This provides an opportunity for extending OR into the social marketing of reproductive health products and services.

CEMOPLAF of Quito, Ecuador is an excellent laboratory for introducing OR into social marketing. The agency is experienced in operations research and uses it in making important program decisions. CEMOPLAF is a leader in sustainability activities in Latin America, and its staff is frequently called upon by other organizations in the region to provide technical assistance. Finally, the agency has a rapidly growing social marketing program that accounts for 36 percent of agency revenues. CEMOPLAF is depending on SM to become the major force in agency sustainability, and wishes to use OR to both improve profitability and quality and increase program scope.

FRONTIERS initiated a long-term relationship with the CEMOPLAF commercial marketing program with a two and a half year (February 1999 - August 2001) project that included both diagnostic studies and capacity building activities. Three studies were conducted: (1) an assessment of program profitability and productivity; (2) a determination of the profile of retail purchasers of CEMOPLAF products; and (3) an evaluation of the quality of information provided to retail purchasers of SM contraceptives. The diagnostic studies are intended to lead to a subsequent round of intervention research to improve productivity, introduce new products and improve the quality of information given to retail purchasers. Capacity building activities included marketing seminars for SM project staff (none of whom were marketing professionals), and training in the design, conduct and analysis of mystery client research. Finally, a regional seminar on sustainability for not-for-profit reproductive health programs, co-sponsored with the USAID funded Commercial Market Strategies (CMS) project was held in Ecuador in May 2001. This final report includes information on the three research projects conducted by CEMOPLAF as well as on the capacity building activities and the regional seminar. 


\section{STUDY I: A FINANCIAL ANALYSIS OF THE CEMOPLAF SOCIAL MARKETING PROGRAM}

Author: John Bratt

\section{Introduction}

\section{A. Background}

Reproductive health programs in developing countries face a major challenge: to provide a greater variety of products and services to a rapidly increasing number of users. This challenge must be met in the context of stagnant or decreasing donor funding. One strategy for providing more services to more people in the face of scarce resources is to shift clients out of highly subsidized services (such as those provided by government programs) to social marketing programs, and ultimately to the commercial sector.

Social marketing has become an increasingly prevalent mechanism for delivering family planning and reproductive health services. In the Latin America and Caribbean (LAC) region, for example, virtually every country receiving USAID funding in recent years has a social marketing program. These programs occupy a middle ground between the public and for-profit sectors. They serve individuals with sufficient resources to pay something for services, although not full commercial sector prices.

Because of sustainability concerns, many social marketing programs are now pursuing strategies to add for-profit product lines in order to cross-subsidize products that are sold at subsidized prices, or even to cross-subsidize clinical or community based (CBD) programs. But little research exists to guide program managers in deciding how to proceed. For example, in almost 15 years the Latin American Operations Research Projects (INOPAL) conducted only three studies with social marketing programs, while carrying out approximately 150 studies with clinical and CBD programs. SM programs have focused their research activities on market surveys, but little sustainability or quality improvement research has been published.

\section{B. Program Setting}

CEMOPLAF is a non-governmental (NGO), not-for-profit organization that operates several reproductive health programs throughout Ecuador, including 21 clinical centers, a rural CBD program, and special programs for adolescents, commercial sex workers, men and indigenous groups. The organization has become known as a leader in sustainability activities in Latin America. CEMOPLAF recovers approximately 80 percent of total operating costs through client fees, and staff are consultants to other LAC reproductive health programs. CEMOPLAF also uses operations research as a routine decision making tool.

In 1996 CEMOPLAF launched its first social marketing project; by 1998 social marketing became the largest single source of locally-generated funds, accounting for approximately 36 percent of gross revenue ( $\$ 67,000$ per month). The SM project sells contraceptive and reproductive health products to pharmacies, physicians, other distributors and non-traditional outlets including liquor stores, hotels, motels and brothels. At the end of 1998 the SM project 
was selling 36 different products, most of which were purchased locally from pharmaceutical supply houses. ${ }^{1}$ In terms of unit sales, the most important are pills $(234,000$ cycles per year), condoms (800,000 packages of three per year), injectable contraceptives $(100,000$ doses per year), and home pregnancy tests (40,000 tests per year). SM executives plan to gradually expand the list of products offered.

In 1998 the project employed 29 full and part-time workers and deployed sales agents in 14 of the 16 cities where CEMOPLAF operates clinics. But rapid growth had left the project with inadequate infrastructure and procedures, particularly for analyzing financial performance. Plans existed for introducing a computerized management information system, but in 1998 project staff were still using a manual system, making basic financial analysis very cumbersome. Moreover, the project had not yet identified basic indicators for assessing overall profitability, productivity of its sales force, or the contribution of specific products to profitability.

\section{Objectives}

The specific objectives of this study were to:

- Conduct a financial analysis to measure profitability of the social marketing project and of individual sales agents; and

- Build capacity for financial analysis within the program so that future studies could be done with minimal external assistance.

The study contributed to the achievement of FRONTIERS' Intermediate Result 3, "capacity for problem solving enhanced within organizations." Prior to the study, decision making in the CEMOPLAF social marketing program was not supported by information on profitability or productivity. It is expected that future decisions will be informed by data on profitability and productivity. The project also contributed to USAID/Ecuador's Intermediate Result 1, "increased sustainability of family planning NGO partners" by strengthening CEMOPLAF's financial control over its SM project, and by explicitly placing strategic emphasis on profitability as the main measure of success.

\section{Methods}

The unit of analysis in this study was the social marketing sales agent. We used a "bottom-up" costing approach to identify and value all of the resources used by sales agents and other CEMOPLAF staff to market SM products. Detailed information follows on methods used to cost different types of resources, and also to calculate program revenues generated by each sales agent.

\footnotetext{
${ }^{1}$ USAID continues to donate contraceptive methods to the program, including condoms, pills, IUDs and injectables.
} 


\section{A. Program Costs}

1. Contraceptives, medicines and other products

CEMOPLAF purchases most SM products from local suppliers of pharmaceuticals. In Ecuadoran commerce, it is common practice for suppliers to deliver more units than a customer actually purchases (usually $10-20$ percent more) as an incentive for future business. These bonus units reduce CEMOPLAF's actual per-unit product cost below the official price negotiated with suppliers. SM accountants reviewed purchase records and calculated unit cost for each product by dividing the total amount paid by the number of units entered into inventory. In this way, unit product costs were adjusted downward to reflect the value of the "bonus units" added to the order by the supplier. Because of volatility in the Ecuadoran economy, product costs were increasing at different rates throughout 1998. It was therefore necessary to calculate unit product costs separately for each month of the year.

Estimated unit costs of donated contraceptives were imputed by determining the cost of purchasing similar products and then adding labor and materials costs to repackage the products.

2. Sales agent compensation

CEMOPLAF accountants provided information on salaries, benefits and sales commissions paid to sales agents in 1998. Total compensation per agent was calculated by summing nominal salary, the 12 separate benefit categories required by Ecuadoran law, and sales commissions.

\section{Administrative support in CEMOPLAF clinics}

Sales agents in all regions except Quito are physically situated in small offices located within CEMOPLAF clinics. ${ }^{2}$ Administrative staff in these clinics provide varying levels of supervision and accounting support to sales agents. We visited each clinic and conducted interviews to determine the proportion of time spent by individual staff members assisting the SM program. The cost of this time was calculated for each administrative staff person by multiplying total annual compensation by the percentage of annual work time dedicated to SM.

\section{Other operating costs}

Sales agents incur a range of other costs in the course of marketing SM products. These include costs of transport, per diem, product-specific advertising, etc. Moreover, the SM program invests resources annually to organize training seminars and meetings for staff. Information on these costs was provided by SM accountants. When feasible, costs corresponding to specific sales agents were taken directly from expenditure records (for example, transport and perdiem, office supplies); costs of resources that benefit the entire SM program (training, advertising) were divided equally among the 25 sales agents working in 1998.

\footnotetext{
${ }^{2}$ In Quito, the 10 sales agents occupy space that is contiguous with the Social Marketing executive office.
} 


\section{Infrastructure and equipment}

Sales agents were assigned a portion of building rent, utilities and housekeeping costs corresponding to the percentage of the CEMOPLAF clinic floor space occupied by the SM office. In facilities owned by CEMOPLAF, we calculated an estimate of equivalent rental value per square meter by averaging the rental charges per square meter in leased facilities.

Annualized costs of office furniture were estimated under the assumption that each sales agent used a basic grouping of a desk, a chair and a filing cabinet. Sales agents also use personal computers for inventory management, record-keeping and reporting. In Quito, each sales agent has exclusive use of a PC, and therefore was assigned the entire annualized cost. In other sites computer resources are shared with clinic staff. Our approach was to assign a portion of the annualized computer cost corresponding to the percentage of time that clinic administrative staff dedicated to the SM program, since the time spent was mainly used to input SM data into the computer. Finally, the SM program owns a vehicle that is used exclusively to support the efforts of the ten sales agents working in Quito. The cost of this vehicle was annualized, and divided equally across these ten sales agents.

\section{B. Sales Revenue}

The SM program charges its customers (pharmacies and physicians) a negotiated price for each unit sold, and also offers in-kind bonuses (usually 10 percent) to encourage future sales. Program accountants provided price lists for each product, by month. Sales revenue for each month was calculated by multiplying the corresponding unit price for each product by the number of units sold.

\section{Results}

\section{A. Overall Profitability}

The objective of the social marketing program is to produce profits that can be used to support other CEMOPLAF programs. Table 1 provides information on total revenue, total costs and net profit for 1998. Sales of products generated revenues of 5.6 billion sucres (approximately US\$1.3 million at the average 1998 exchange rate). CEMOPLAF paid over 3.9 billion sucres (US\$715,000) to acquire these products from suppliers, leaving a gross profit of nearly 1.7 billion sucres (US\$300,000). Costs of running the program - including sales, marketing and management - totaled 1.1 billion sucres (US\$198,000). Net profit for 1998 was 563 million sucres (US\$103,000), representing a 10 percent return on sales volume. 
Table 1: Calculation of Net Profit, CEMOPLAF Social Marketing Program, 1998

\section{Millions of 1998 Sucres}

\section{Sales Revenue}

Cost of Goods Sold

Gross Profit

Other Program Costs

Personnel

Training

Advertising

Other Recurrent Costs

Equipment

Infrastructure

Program Overhead
5,631

$\underline{3,967}$

1,664

612

23

94

95

33

79

$\underline{165}$

$\underline{1,101}$

563

\section{B. Uses of Program Income}

Figure 1 consolidates information in Table 1 to provide a graphical representation of how CEMOPLAF used the income generated by the SM program in 1998. Seventy percent of sales revenue was used to cover product costs. Program costs (including staff, supplies, advertising and other costs) and program overhead consumed an additional 20 percent, leaving a profit margin of 10 percent.

Figure 1: Uses of Social Marketing Income, CEMOPLAF 1998

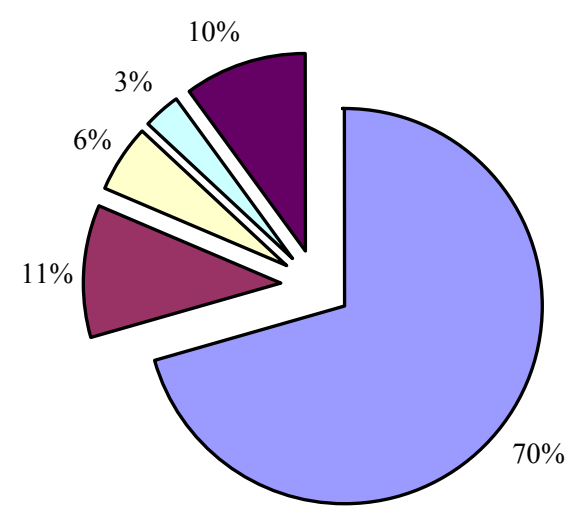

$\square_{\text {Cost of Goods Sold }}$

口Personnel Costs

$\boldsymbol{\square}_{\text {Other Direct Costs }}$

$\square$ Program Overhead

$\boldsymbol{\square}_{\text {Net Profit }}$ 


\section{Differences in Net Revenue by Product}

In 1998 the SM product list included 36 different items, of which 19 were contraceptive methods. ${ }^{3}$ Table 2 presents information on net revenue per unit for a subset of products. Net revenue is defined as sales revenue minus product cost, and represents the margin earned from each unit of sales that is available to cover other program costs. Net revenue varies substantially, from a high of US $\$ 4.00$ to a low of US\$- 0.02 ; average net revenue per unit is US\$1.46. The highest-selling brands tend to be those with lower per-unit margins, such as the Protektor condom brand and LoFemenal oral contraceptives.

Table 2: Net Revenue per Unit for Selected Social Marketing Products, in 1998 Sucres $($ SUS1 $=5450 \mathrm{~S} /$.)

\begin{tabular}{|l|c|}
\hline Top Five & $\begin{array}{c}\text { Net Revenue per Unit } \\
\text { (US\$ in parentheses) }\end{array}$ \\
\hline Clamox cream & $21,840(4.00)$ \\
\hline Mobic 15 & $20,400(3.74)$ \\
\hline Gynera CD & $19,748(3.62)$ \\
\hline Marvelon & $18,450(3.39)$ \\
\hline Clamox & $18,159(3.33)$ \\
\hline Bottom Five & \\
\hline Protektor & $2,412(0.44)$ \\
\hline Copper T 380A & $1,726(0.32)$ \\
\hline LoFemenal & $1,542(0.28)$ \\
\hline Nordette MD & $936(0.17)$ \\
\hline Conceptrol & $-95(-0.02)$ \\
\hline Average of all Products & $7,936(1.46)$ \\
\hline
\end{tabular}

\section{Profitability by Region}

Approximately half of the SM sales agents work in either Quito or Guayaquil (the two major urban areas of Ecuador), while the remaining agents work in smaller cities. Figure 2 shows differences in productivity and profitability between the two regions. The lighter-shaded bar represents gross profit, which equals sales revenue minus product costs (the same concept as net revenue, only on an aggregate basis). The darker bar represents program costs, which equal total SM costs excluding product costs. Agents working in Quito-Guayaquil produced nearly twice as much gross profit as agents working in smaller cities, and accounted for more than 80 percent of SM total net profits (shown by the difference between the gross profit and and program cost bars).

\footnotetext{
${ }^{3}$ These methods included 11 brands of OCs, five formulations of injectables, one brand of condoms, an IUD and a contraceptive foaming tablet.
} 


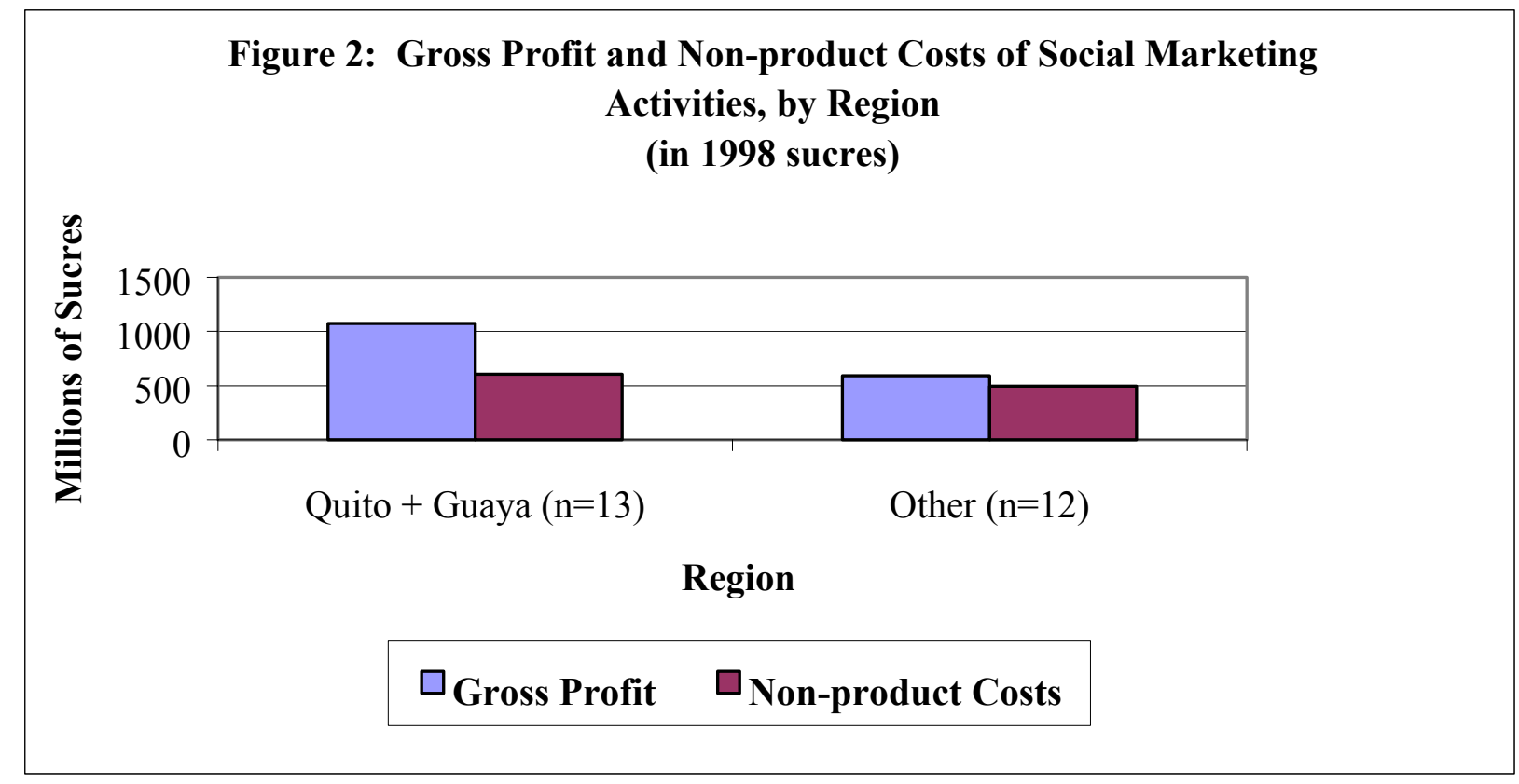

Differences between the two regions in productivity and profitability are related to sales volume and to a lesser degree, composition of sales. All agents incur the same product costs, and program costs are similar between the two regions. The key factor is gross profit; each agent must produce approximately $\mathrm{S} / .45-50$ million (US $\$ 8,200-\$ 9,200$ ) in gross profit in order to break even. ${ }^{4}$ Gross profits can be increased by selling more products overall (sales volume) or selling more of the most profitable products (composition of sales). Since the Quito-Guayaquil region has a larger number of potential SM customers (pharmacies and physicians) and a more diverse and commercialized market, it is easier for sales agents to generate gross profits (and therefore net profits) in this region.

\section{E. Profitability of Sales Agents}

Figure 3 presents information on profitability of CEMOPLAF's 25 sales agents. Each data point represents one sales agent, and points are divided according to the two main regions: black diamonds correspond to agents working in Quito-Guayaquil, and gray dots represent agents working in other cities. The diagonal line shows all possible points where the agent "breaks even", i.e. where gross profit (sales revenue minus product cost) exactly equals program costs. Points lying above the diagonal line indicate profitable sales agents. All but two of the QuitoGuayaquil sales agents earned net profits, while the majority of agents working in other cities either lost money or earned small net profits. ${ }^{5}$

\footnotetext{
${ }^{4}$ Gross profit is more useful as an indicator of productivity than sales revenue, because unit profit margins vary substantially across products. As an example, consider the difference between two agents: one sells US $\$ 20,000$ in low-margin products, and generates gross profits of US $\$ 5,000$; the other sells US $\$ 15,000$ in high-margin products and generates gross profits of US\$7,000. The first agent produces more sales revenue, but the second agent generates more net revenue.

${ }_{5}^{5}$ Notable exceptions included sales agents in Riobamba (Jaramillo), Latacunga (Mayorga), and Santo Domingo (Aguirre).
} 


\section{Figure 3: Profitability of Individual Sales Agents, by Region, CEMOPLAF 1998 (in millions of sucres)}

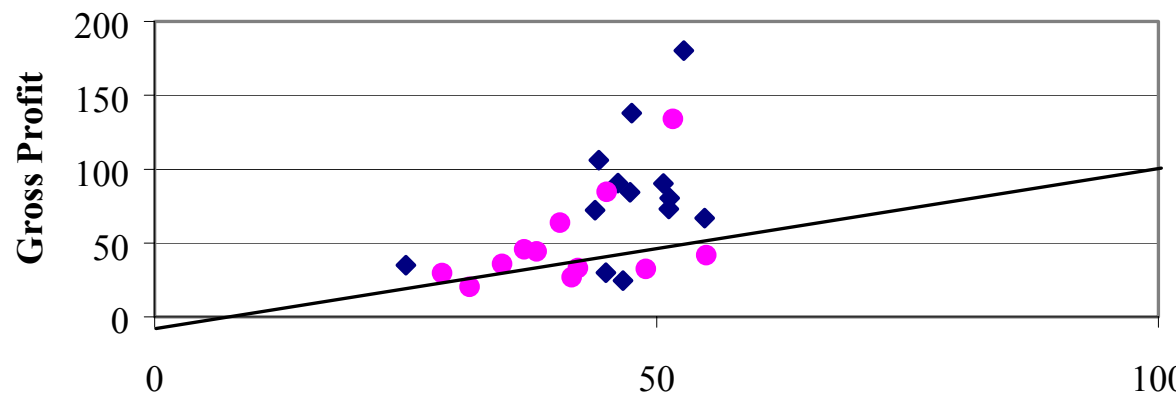

Sales Agent Costs

$\bullet$ Quito - Guayaquil $\quad$ Other

\section{Conclusions and Recommendations}

\section{A. Conclusions}

1. The social marketing project was profitable during the calendar year 1998, generating $\$ 103,000$ in net profits to be used by CEMOPLAF management to support other activities. Return on sales revenue was 10 percent. We cannot say how this result compares with financial performance of other SM programs because our literature searches found no references to other studies on profitability of social marketing. But even if such studies do exist, it is unlikely that results would be comparable because of the economic cost focus used in our study.

2. The condom brand Protektor brought in the most revenue of any product, and contributed the highest total gross profits. Protektor's dominance was due to high sales volume, since the product is near to the bottom of the list of net revenue per unit sold.

3. Half of the sales force is responsible for nearly all of the profits, and most of these agents work in Quito-Guayaquil. Seven of 25 agents lost money.

4. Other important long-term impacts of this study include: (a) SM executives now have the tools to analyze financial performance from a profitability perspective; (b) sales agents will have access to better information for tracking unit profit margins, trends in sales volume, and the financial performance of their own regions. 


\section{B. Recommendations}

1. The SM program should use gross profit as the key indicator of productivity for sales agents. Gross profit is a better indicator of success than sales revenue, because sales revenue does not account for product costs.

2. The SM program should evaluate current compensation policy for sales agents. Sales bonuses range from $0 \%$ to 10 percent of salaries, with most sales agents clustered in a 1 3 percent band. It is unlikely that this bonus structure serves as a real incentive to agents to sell more products. One idea would be to test an alternative compensation policy where fixed salaries were substantially reduced, and sales agents were given opportunity to earn substantial bonuses on gross profit.

3. The SM program should assess whether some of the smaller cities have a large enough market to justify a dedicated SM presence, and consider eliminating or consolidating sales areas.

4. The SM program should routinely collect, analyze and distribute information similar to the data generated in this study. For example, sales agents should have current information on net revenue by product, to know which products contribute the most to profitability. Also, the SM program could make annual projections of non-product costs for each sales agent (i.e., salary, transport, training, etc.) and then provide feedback to sales agents on gross profits generated each month. Such a system would allow SM management and each sales agent to track progress toward the break-even point. 


\section{STUDY II: MARKET ASSESSMENT FOR CEMOPLAF PRODUCTS: CUSTOMER PROFILE}

Authors: Dr. Laura C. Altobelli and Ana María Buller

\section{Introduction}

Social marketing is recently becoming recognized as an important channel for delivering family planning and reproductive health services. It is a service-delivery strategy that has developed out of the increasing demand for these services in the face of ever decreasing donor support. The strategy involves shifting clients from government programs to partially subsidized social marketing programs, and eventually to the commercial sector. Target clients are those who have sufficient resources to pay something for services, although not full commercial sector prices. In order to strengthen program sustainability, social marketing programs are now moving more into commercial marketing by adding for-profit product lines in order to cross-subsidize products or services that are sold at lower, subsidized prices.

CEMOPLAF of Quito, Ecuador is a private non-profit organization that provides reproductive health services and products. The organization has grown to include 21 reproductive health clinical centers, a rural CBD program, and special programs for adolescents, men, and indigenous groups in 14 cities of Ecuador. In the area of program sustainability, CEMOPLAF serves as a model for Latin America. Over 80 percent of CEMOPLAF costs are recuperated. The largest portion of cost-recovery comes from social marketing activities. CEMOPLAF sells contraceptive and reproductive health products to pharmacies, physicians, other distributors, and non-traditional outlets including liquor stores, hotels, motels and brothels.

Within FRONTIERS' global research agenda in sustainability, CEMOPLAF has been identified as a key program for developing and conducting operations research in social marketing for sustainability. CEMOPLAF wishes the program to become more commercial and capable of generating income that will be used to subsidize other projects. To do so, CEMOPLAF will have to build market share, add products, and expand into new markets. One of the steps for CEMOPLAF to reach this goal is to better understand its products' market share, the size of the market for them, the socio-demographic profile of the current and potential purchasers of its products, and other aspects including analyses of finances and quality of services.

The present document is a report on a market assessment study conducted to profile the customers in commercial pharmacies where CEMOPLAF products are sold.

\section{METHODOLOGY}

We conducted point of purchase interviews in five cities with the largest market for CEMOPLAF products: Quito, Guayaquil, Santo Domingo de los Colorados, Riobamba, and Ambato. 


\section{A. Sample Selection}

Sampling was done in two stages. A random sample of retail outlets selling CEMOPLAF projects was drawn in each of the five cities. The number selected was roughly proportional to the city's population: 15 in Quito, 15 in Guayaquil, 10 in Santo Domingo, 5 in Riobamba, and 5 in Ambato for a total sample of 50 retail pharmacies. The sample in each city was stratified by size of the pharmacy (large, medium, and small), determined by the average number of customers per day. ${ }^{1}$ All persons exiting the selected pharmacies during pharmacy hours were interviewed for a period of five consecutive days. All exiting customers who had made a purchase in the pharmacy were asked to respond to the full questionnaire. ${ }^{2}$ The total number of interviews of purchasing customers was 8,942 .

\section{B. Data Collection}

Interviewers were CEMOPLAF personnel who had received prior training in interviewing techniques. The questionnaire consisted primarily of closed-ended questions. Information was collected on the interviewee's sociodemographic characteristics, home and work location, reason for purchasing in that particular pharmacy, medicine or product purchased that day, intended recipient, ability to find all desired products, and those that had not been found.

\section{Results}

\section{A. Socioeconomic Characteristics of Study Population}

The socioeconomic characteristics of the study participants differed among the five cities, as shown on Table 1. Education was positively associated with size of the city. Guayaquil had the best-educated pharmacy clientele at 77.2 percent with secondary or higher education, followed by Quito with 68 percent. The smallest city studied, Ambato, had the lowest percentage with secondary or higher education $(59.5 \%)$, as well as the highest proportion of clients with no formal education (8\%). Educational level is important when considering what type of advertising and promotion is most effective.

Pharmacy clients had a median age of 33 years, though the distribution in each city varied. Santo Domingo had a significantly lower proportion of persons over 45 than the other four cities. This has implications for the types of pharmaceutical products they would be likely to purchase.

In all cities, females were more likely than males to be pharmacy purchasers. Size of city was associated with male purchasing, ranging from a high of 48 percent male purchasers in Guayaquil to a low of 39.1 percent male in Riobamba (Table 1).

\footnotetext{
${ }^{1}$ The sample of pharmacies utilized was the same as that used for the mystery client study.

${ }^{2}$ The first day of data collection, interviewees received a small incentive gift for their participation. This was immediately identified as a stimulus for repeat purchases, and the practice was stopped for the remainder of the study.
} 
Percentage of married or in-union pharmacy users ranged from 62 percent in Guayaquil to 71.1 percent in Ambato. The remainder was single or had 'other' civil status.

Interviewees reported up to three different products purchased. If any one was a CEMOPLAF product, the person was coded as a CEMOPLAF purchaser. The highest proportions of

CEMOPLAF product buyers were in Santo Domingo with 11.7 percent and Riobamba with 8.9 percent. The lowest percentage (3.9\%) was in Guayaquil.

Table 1: Characteristics of Study Population in Pharmacies by City

\begin{tabular}{|c|c|c|c|c|c|}
\hline \multirow{2}{*}{ Characteristics of users } & \multicolumn{5}{|c|}{ CITY* } \\
\hline & Quito (\%) & Guayaquil (\%) & Sto. Domingo (\%) & Riobamba (\%) & Ambato (\%) \\
\hline \multicolumn{6}{|l|}{ Education } \\
\hline None & 2.4 & 2.4 & 3.2 & 3.8 & 8.0 \\
\hline Primary & 29.7 & 20.4 & 41.8 & 32.1 & 42.5 \\
\hline Secondary & 44.6 & 54.0 & 49.1 & 40.8 & 30.4 \\
\hline Superior & 23.4 & 23.2 & 5.9 & 23.3 & 29.1 \\
\hline \multicolumn{6}{|l|}{ Age Group } \\
\hline$<15$ & 6.9 & 3.5 & 4.4 & 4.5 & 5.5 \\
\hline $15-24$ & 21.9 & 19.8 & 25.8 & 20.4 & 20.3 \\
\hline $25-34$ & 23.6 & 27.5 & 28.5 & 24.8 & 22.7 \\
\hline $35-44$ & 21.7 & 24.8 & 26.9 & 21.7 & 21.0 \\
\hline 45 or more & 25.9 & 24.4 & 14.5 & 28.7 & 30.5 \\
\hline \multicolumn{6}{|l|}{ Sex } \\
\hline Female & 56.0 & 51.8 & 56.8 & 60.9 & 58.2 \\
\hline Male & 44.0 & 48.2 & 43.2 & 39.1 & 41.8 \\
\hline \multicolumn{6}{|l|}{ Marital status } \\
\hline Has partner & 66.3 & 62.0 & 69.2 & 67.2 & 71.1 \\
\hline No partner & 33.7 & 38.0 & 30.8 & 32.8 & 28.9 \\
\hline \multicolumn{6}{|l|}{ Source of products purchased } \\
\hline CEMOPLAF product & 6.3 & 3.9 & 11.7 & 8.9 & 6.3 \\
\hline Other commercial product & 93.7 & 96.1 & 88.3 & 91.1 & 93.7 \\
\hline $\mathrm{N}=$ & 2993 & 2675 & 586 & 942 & 1746 \\
\hline
\end{tabular}

* Quito - Capital of Ecuador in Andes mountains.

Guayaquil - Principal commercial/shipping center for Ecuador on coast.

Santo Domingo - Medium size provincial capital on inland coast.

Riobamba - Medium size provincial capital in Andes mountains.

Ambato - Small provincial capital in Andes mountains

\section{Profile of Pharmaceutical Purchasers - CEMOPLAF versus Non-CEMOPLAF}

For market identification purposes it is useful to investigate whether there are any differences between the characteristics of people buying CEMOPLAF products and those buying products from other sources. 
Table 2 presents a comparison of characteristics of CEMOPLAF product buyers and purchasers of other products. According to the table, there was no significant difference in education between the two groups.

Table 2: Profile of All Pharmacy Purchasers by Source of Products Purchased

\begin{tabular}{|l|c|c|c|}
\hline \multirow{2}{*}{ Characteristics of users } & \multicolumn{3}{|c|}{ SOURCE OF PRODUCTS } \\
\cline { 2 - 4 } & CEMOPLAF (\%) & OTHERS (\%) & $\begin{array}{c}\text { Chi-square } \\
\text { P value }\end{array}$ \\
\hline Education & $\mathbf{2 . 4}$ & $\mathbf{3 . 1}$ & \\
None & $\mathbf{3 2 . 6}$ & $\mathbf{3 0 . 2}$ & No \\
Primary & $\mathbf{4 5 . 4}$ & $\mathbf{4 7 . 1}$ & significance \\
Secondary & $\mathbf{1 9 . 5}$ & $\mathbf{1 9 . 6}$ & $(3 \mathrm{df})$ \\
Superior & & $\mathbf{5 . 2}$ & \\
\hline Age Group & $\mathbf{3 . 4}$ & $\mathbf{2 1 . 6}$ & \\
& $\mathbf{2 3 . 8}$ & $\mathbf{2 5 . 4}$ & $<0.001$ \\
$15-24$ & $\mathbf{3 1 . 4}$ & $\mathbf{2 3 . 2}$ & $(4 \mathrm{df})$ \\
$25-34$ & $\mathbf{2 8 . 4}$ & $\mathbf{2 4 . 6}$ & \\
$35-44$ & $\mathbf{1 3 . 0}$ & $\mathbf{5 5 . 0}$ & $<0.001$ \\
45 or more & $\mathbf{6 3 . 3}$ & $\mathbf{4 5 . 0}$ & (4 df) \\
\hline Sex $\quad$ Female & $\mathbf{3 6 . 7}$ & $\mathbf{8 3 2 3}$ & \\
\hline Male & $\mathbf{6 1 9}$ & & \\
\hline $\mathrm{N}=\quad$ & &
\end{tabular}

There was a significant difference in age between the two groups. About 84 percent of CEMOPLAF purchasers were 15 to 44 years of age, with just 70.2 percent of non-CEMOPLAF product purchasers in this age group. The age difference is likely due to CEMOPLAF's concentration on selling contraceptives and other products used by women of fertile age. CEMOPLAF purchasers were significantly more likely than other product buyers to be female, as is consistent with the reproductive health orientation of the CEMOPLAF product line.

\section{Profile of Contraceptive Purchasers - CEMOPLAF versus Non-CEMOPLAF}

Contraceptives are the major products sold by CEMOPLAF, and CEMOPLAF contraceptives are 92.5 percent of all contraceptives sold. Table 3 shows the distribution of educational level, age group, sex, and partner status of CEMOPLAF contraceptive purchasers. These data are contrasted in the same table with the 26 people who bought other brands of contraceptives.

In terms of educational attainment, those who bought CEMOPLAF contraceptives had an overall lower level than persons buying other contraceptive brands. Thirty-seven percent of CEMOPLAF contraceptive purchasers had less than secondary education versus only 19.2 percent of other contraceptive brand buyers. In terms of age, 70.3 percent of CEMOPLAF contraceptive buyers were in the 25 to 44 year age group. In contrast, 50 percent of other brand buyers were in that age group. Females were 63 percent of all CEMOPLAF contraceptive purchasers, and 69.2 percent of non-CEMOPLAF contraceptive buyers. 
Table 3: Profile of Contraceptive Purchasers by Source of Product

\begin{tabular}{|c|c|c|c|c|}
\hline \multirow{3}{*}{ Characteristics of users } & \multicolumn{4}{|c|}{ SOURCE OF PRODUCTS } \\
\hline & \multicolumn{2}{|c|}{ CEMOPLAF } & \multicolumn{2}{|c|}{ OTHERS } \\
\hline & $\%$ & $\mathrm{~N}$ & $\%$ & $\mathrm{~N}$ \\
\hline \multicolumn{5}{|l|}{ Education } \\
\hline None & 1.9 & 6 & - & - \\
\hline Primary & 35.4 & 113 & 19.2 & 5 \\
\hline Secondary & 45.8 & 146 & 42.3 & 11 \\
\hline Superior & 16.9 & 54 & 38.5 & 10 \\
\hline Total & 100 & 319 & 100 & 26 \\
\hline \multicolumn{5}{|l|}{ Age Group } \\
\hline$<15$ & 1.6 & 5 & 3.8 & 1 \\
\hline $15-24$ & 24.0 & 76 & 23.1 & 6 \\
\hline $25-34$ & 37.2 & 118 & 19.2 & 5 \\
\hline $35-44$ & 33.1 & 105 & 30.8 & 8 \\
\hline 45 or more & 4.1 & 13 & 23.1 & 6 \\
\hline Total & 100 & 317 & 100 & 26 \\
\hline \multicolumn{5}{|l|}{$\underline{\operatorname{Sex}}$} \\
\hline Female & 62.9 & 200 & 69.2 & 18 \\
\hline Male & 37.1 & 118 & 30.8 & 8 \\
\hline Total & 100 & 318 & 100 & 26 \\
\hline \multicolumn{5}{|l|}{ Has partner } \\
\hline Yes & 78.0 & 245 & 72.0 & 18 \\
\hline No & 22.0 & 69 & 28.0 & 7 \\
\hline Total & 100 & 314 & 100 & 25 \\
\hline
\end{tabular}

\section{B. Characterization Of CEMOPLAF Products Purchased}

\section{Types of Products Purchased}

Contraceptives account for 44.5 percent of all CEMOPLAF product sales, as shown in Table 4 . Contraceptives are followed in sales volume by antispasmodics (15.4\% of all CEMOPLAF sales), antibacterials/antimicrobials/antivirals (11.2\%), cough suppressants (6.3\%), laxatives (4.3\%), anti-inflammatory drugs (3.8\%), and cold remedies (3.5\%). The non-CEMOPLAF products most frequently purchased were: analgesics (15.5\%), antimicrobials/antivirals (14.2\%), and anti-inflammatory drugs (13\%). These are drugs that could be more strongly promoted by CEMOPLAF to capture some of the market going to other brands of those drugs. 
Table 4: Types of Products Purchased in Pharmacies by Source

\begin{tabular}{|l|c|c|c|c|}
\hline \multirow{2}{*}{ Types of Products* } & \multicolumn{4}{|c|}{ SOURCE OF PRODUCTS } \\
\cline { 2 - 5 } & \multicolumn{2}{|c|}{ CEMOPLAF } & \multicolumn{2}{c|}{ OTHERS } \\
\cline { 2 - 5 } & $\%$ & $\mathrm{~N}$ & $\%$ & $\mathrm{~N}$ \\
\hline Contraceptives & $\mathbf{4 4 . 5}$ & 320 & $\mathbf{0 . 3}$ & 27 \\
Antispasmodics & $\mathbf{1 5 . 4}$ & 111 & $\mathbf{2 . 9}$ & 305 \\
Antibacterials, anti-microbials, antivirals & $\mathbf{1 1 . 2}$ & 81 & $\mathbf{1 4 . 2}$ & 1503 \\
Cough suppressants & $\mathbf{6 . 3}$ & 45 & $\mathbf{2 . 4}$ & 253 \\
Laxatives & $\mathbf{4 . 0}$ & 29 & $\mathbf{0 . 2}$ & 22 \\
Pregnancy tests & $\mathbf{1 . 8}$ & 13 & $\mathbf{0 . 0 5}$ & 5 \\
Anti-inflamatories & $\mathbf{3 . 8}$ & 27 & $\mathbf{1 3 . 0}$ & 1371 \\
Cold remedies & $\mathbf{3 . 5}$ & 25 & $\mathbf{6 . 4}$ & 671 \\
Vitamins & $\mathbf{1 . 3}$ & 9 & $\mathbf{9 . 7}$ & 1026 \\
Anti-helminths & $\mathbf{0 . 8}$ & 6 & $\mathbf{2 . 1}$ & 223 \\
Anti-mycotics & $\mathbf{0 . 7}$ & 5 & $\mathbf{1 . 6}$ & 174 \\
Analgesics & $\mathbf{2 . 2}$ & 16 & $\mathbf{1 5 . 3}$ & 1620 \\
Other & $\mathbf{4 . 4}$ & 32 & $\mathbf{3 1 . 9}$ & 3365 \\
\hline Total & $\mathbf{1 0 0}$ & $\mathbf{7 1 9}$ & $\mathbf{1 0 0}$ & $\mathbf{1 0 5 6 5}$ \\
\hline
\end{tabular}

*Classification of medicine products was done by CEMOPLAF medical consultants.

2. Types of Contraceptives Purchased

A list of specific CEMOPLAF contraceptives purchased in the study pharmacies is shown in Table 5. Oral contraceptives were by far the most frequently sold type of CEMOPLAF product, accounting for 52.8 percent of CEMOPLAF contraceptive sales, led by the brands Lo Femenal (29.7\%) and Microgynon (14.1\%). OCs were followed by condoms at 29.7 percent, injectables at 17.5 percent, and barrier methods at 0.3 percent.

Oral contraceptives accounted for one-half of all non-CEMOPLAF contraceptive sales, led by the brand Triquilar (19.2\%). The single most frequently purchased non-CEMOPLAF contraceptive was Norform vaginal tablets (34.6\%). The injectable contraceptive Gynodian comprised 15.4 percent of the non-CEMOPLAF contraceptive market. No condoms were sold in the study pharmacies that were non-CEMOPLAF brands. 
Table 5: Types of Contraceptives Purchased in Pharmacies by Source

\begin{tabular}{|c|c|c|}
\hline \multirow{2}{*}{ Type and Brand } & \multicolumn{2}{|c|}{ SOURCE OF PRODUCTS } \\
\cline { 2 - 3 } & CEMOPLAF (\%) & OTHER (\%) \\
\hline Oral Contraceptives & $\mathbf{2 9 . 7}$ & - \\
Lo Femenal & $\mathbf{1 4 . 1}$ & - \\
Microgynon & $\mathbf{1 . 6}$ & - \\
Nordette & $\mathbf{0 . 6}$ & - \\
Duofen & $\mathbf{0 . 3}$ & - \\
Gynera & $\mathbf{1 . 2}$ & - \\
Exluton & - & $\mathbf{1 9 . 2}$ \\
Triquilar & - & $\mathbf{7 . 7}$ \\
Neogynon & - & $\mathbf{7 . 7}$ \\
Diane & - & $\mathbf{7 . 7}$ \\
Climene & - & $\mathbf{3 . 8}$ \\
Climatrol & - & $\mathbf{3 . 8}$ \\
Rainobow & $\mathbf{1 6 . 6}$ & - \\
Injectables & $\mathbf{5 . 0}$ & - \\
Topasel & $\mathbf{0 . 9 4}$ & - \\
Mesigyna & - & $\mathbf{1 5 . 4}$ \\
Depo Provera & $\mathbf{2 9 . 7}$ & - \\
Gynodian & & - \\
Condom & $\mathbf{0 . 3}$ & $\mathbf{3 4 . 6}$ \\
\hline Vaginal Tablets & - & $\mathbf{1 0 0}$ \\
\hline Conceptrol & $\mathbf{1 0 0}$ & $\mathbf{2 6}$ \\
Norforms & $\mathbf{3 2 0}$ & \\
\hline Total & & \\
\hline N $=$ & & \\
\hline
\end{tabular}

3. Types of Pregnancy Tests Purchased

Table 6 shows the types and sources of pregnancy tests purchased. Of 17 pregnancy tests purchased by study subjects, 13 (76.5\%) were CEMOPLAF brands.

Table 6: Types of Pregnancy Tests Purchased in Pharmacies by Source

\begin{tabular}{|l|c|c|c|c|}
\hline \multirow{2}{*}{ Brand } & \multicolumn{4}{|c|}{ SOURCE OF PRODUCTS } \\
\cline { 2 - 5 } & \multicolumn{2}{|c|}{ CEMOPLAF } & \multicolumn{2}{c|}{ OTHERS } \\
\cline { 2 - 5 } & $\%$ & $\mathrm{~N}$ & $\%$ & $\mathrm{~N}$ \\
\hline Detector & $\mathbf{5 3 . 8}$ & 7 & - & - \\
Pecolor PE & $\mathbf{4 6 . 2}$ & 6 & - & - \\
Affirm PE & - & - & $\mathbf{5 0 . 0}$ & 2 \\
Cliane & - & - & $\mathbf{5 0 . 0}$ & 2 \\
\hline Total & $\mathbf{1 0 0}$ & $\mathbf{1 3}$ & $\mathbf{1 0 0}$ & $\mathbf{4}$ \\
\hline
\end{tabular}




\section{For Whom Product Was Purchased}

Table 7 shows that approximately half of all pharmaceutical purchases were made for people other than the purchaser him/herself, with men purchasing for themselves in 55 percent of the cases and females for themselves in 50.4 percent. Purchases made for one's spouse/partner accounted for 10.4 percent of male purchases and 4.7 percent of female purchases. Twenty percent of female purchases were made for their own child, while this held true for about 10 percent of men's purchases. For both men and women, purchases were frequently made for persons older than the purchaser him/herself, such as a mother/father, aunt/uncle, or grandparent (13\% of purchases).

Table 7: For Whom Product Was Purchased, by Gender of Interviewee

\begin{tabular}{|l|c|c|}
\hline \multirow{2}{*}{ For whom product was purchased } & \multicolumn{2}{|c|}{ GENDER OF INTERVIEWEE } \\
\cline { 2 - 3 } & Male $(\%)$ & Female (\%) \\
\hline Self & $\mathbf{5 5 . 1}$ & $\mathbf{5 0 . 4}$ \\
Spouse or partner & $\mathbf{1 0 . 4}$ & $\mathbf{4 . 7}$ \\
Son/daughter & $\mathbf{9 . 8}$ & $\mathbf{1 9 . 5}$ \\
Another older person & $\mathbf{1 2 . 7}$ & $\mathbf{1 3 . 0}$ \\
Another person of same age & $\mathbf{7 . 8}$ & $\mathbf{7 . 4}$ \\
Another younger person & $\mathbf{2 . 2}$ & $\mathbf{3 . 4}$ \\
Other & $\mathbf{2 . 0}$ & $\mathbf{1 . 6}$ \\
\hline Total & $\mathbf{1 0 0}$ & $\mathbf{1 0 0}$ \\
\hline $\mathrm{N}=$ & $\mathbf{3 9 7 0}$ & $\mathbf{4 9 6 9}$ \\
\hline
\end{tabular}

Table 8 shows that pregnancy tests and non-contraceptive medicines were approximately divided among purchases for self and for others. Contraceptives, on the other hand, were purchased for oneself in 81.7 percent of those cases.

Table 8: For Whom Pharmaceutical Product Was Purchased, by Type of Product

\begin{tabular}{|l|c|c|c|c|}
\cline { 2 - 5 } \multicolumn{1}{c|}{} & \multicolumn{3}{c|}{ TYPE OF PRODUCT } \\
\hline $\begin{array}{l}\text { For whom product } \\
\text { was purchased }\end{array}$ & $\begin{array}{c}\text { Contraceptives } \\
(\%)\end{array}$ & $\begin{array}{c}\text { Pregnancy Test } \\
(\%)\end{array}$ & $\begin{array}{c}\text { Medicine } \\
(\%)\end{array}$ & $\begin{array}{c}\text { Total } \\
(\%)\end{array}$ \\
\hline Self & $\mathbf{8 1 . 7}$ & $\mathbf{4 6 . 2}$ & $\mathbf{4 9 . 3}$ & $\mathbf{6 5 . 0}$ \\
\hline Other & $\mathbf{1 8 . 3}$ & $\mathbf{5 3 . 8}$ & $\mathbf{5 0 . 7}$ & $\mathbf{3 5 . 0}$ \\
\hline $\mathrm{N}=$ & $\mathbf{3 0 0}$ & $\mathbf{1 3}$ & $\mathbf{3 0 6}$ & $\mathbf{6 1 9}$ \\
\hline
\end{tabular}

5. Use of Physician Prescription for Pharmaceutical Purchase

The effect of physician prescription on purchase of CEMOPLAF products is shown in Table 9. On average, 34.6 percent of all CEMOPLAF oral contraceptives and 28.9 percent of injectable contraceptives were purchased with a prescription. Prescriptions were generally not used for condom purchases. Among non-contraceptive CEMOPLAF products sold, an average of 26.1 
percent were purchased with a physician prescription. The large proportion of pharmaceutical products sold without a prescription is not altogether unusual for the Latin American region. This information can help CEMOPLAF identify which products are being successfully promoted through private physicians, and which could be more strongly promoted.

Table 9: Purchase of CEMOPLAF Products with or without Medical Prescription

\begin{tabular}{|c|c|c|c|}
\hline \multirow[t]{2}{*}{ CEMOPLAF Products } & $\begin{array}{l}\text { Purchased with } \\
\text { prescription }\end{array}$ & $\begin{array}{l}\text { Purchased without } \\
\text { prescription }\end{array}$ & Tota \\
\hline & $\%$ & $\%$ & $\mathbf{N}$ \\
\hline \multicolumn{4}{|l|}{ Oral Contraceptives } \\
\hline Lo Femenal & 40.0 & 60.0 & 90 \\
\hline Microgynon & 17.8 & 82.2 & 45 \\
\hline Nordette & 50.0 & $\mathbf{5 0 . 0}$ & 4 \\
\hline Duofen & - & 100 & 2 \\
\hline Gynera & 100 & - & 1 \\
\hline Exluton & - & 100 & 2 \\
\hline Total & 34.6 & 65.4 & 144 \\
\hline \multicolumn{4}{|l|}{ Injectables } \\
\hline Topasel & 46.7 & 53.3 & 45 \\
\hline Mesigyna & 40.0 & 60.0 & 15 \\
\hline Depo Provera & - & 100 & 3 \\
\hline Total & 28.9 & 71.1 & 63 \\
\hline \multicolumn{4}{|l|}{ Condom } \\
\hline Total & 1.1 & 98.9 & 92 \\
\hline \multicolumn{4}{|l|}{ Vaginal Tablets } \\
\hline Conceptrol & 100 & - & 1 \\
\hline Total & 100 & - & 1 \\
\hline \multicolumn{4}{|l|}{ Pregnancy Tests } \\
\hline Pecolor PE & - & 100 & 6 \\
\hline Detector & 14.3 & 85.7 & 7 \\
\hline Total & 7.7 & 92.3 & 13 \\
\hline \multicolumn{4}{|c|}{ Other CEMOPLAF Medicine } \\
\hline Bisolvon & 16.1 & 83.9 & 31 \\
\hline Buscapina & 6.9 & 93.1 & 72 \\
\hline Bacterol & 48.1 & 51.9 & 27 \\
\hline Rotopar & 100 & - & 6 \\
\hline Compofen & 27.3 & 72.7 & 11 \\
\hline Clamox & 87.5 & 12.5 & 8 \\
\hline Mobic & 33.3 & 66.7 & 12 \\
\hline Ducolax & 13.0 & 87.0 & 23 \\
\hline Neogripal & 9.1 & 90.9 & 11 \\
\hline Trigentax & 42.9 & 57.1 & 7 \\
\hline Bacticel & 83.3 & 16.7 & 6 \\
\hline Doxifen & - & 100 & 1 \\
\hline Invigan & 100 & - & 2 \\
\hline Materna & 33 & 66.7 & 3 \\
\hline Total & 26.1 & 73.9 & 220 \\
\hline
\end{tabular}




\section{Reasons for Utilization of Study Pharmacies}

The data presented in Table 10 compares CEMOPLAF product purchasers with purchasers of non-CEMOPLAF products based on the reasons for shopping at the pharmacy in which they were interviewed. Convenience was the major reason for using a particular pharmacy for purchase, accounting for 28.9 percent and 31.7 percent of the two groups, respectively. From there, the two groups diverge somewhat in their stated motivations. Seventeen percent of CEMOPLAF users purchased at that particular pharmacy because they perceived costs were lower, 14.5 percent because of random chance, 14.1 percent because they received better treatment there, and 8.1 percent because they had greater confidence in that pharmacy due to a personal relationship with the owner. Among non-CEMOPLAF product purchasers, aside from the most important reason of convenience, 15.5 percent shopped at that particular pharmacy due to random chance, 13.0 percent because costs were lower, 12.0 percent because they had greater confidence, and 11.1 percent because they received better treatment there.

Table 10: Reasons Given for Using Pharmacy, Comparing Purchasers of CEMOPLAF and Non-CEMOPLAF Products

\begin{tabular}{|l|c|c|}
\hline \multirow{2}{*}{ Reasons for using pharmacy } & \multicolumn{2}{|c|}{ SOURCE OF PRODUCTS } \\
\cline { 2 - 3 } & CEMOPLAF (\%) & OTHERS (\%) \\
\hline Convenience & $\mathbf{2 8 . 9}$ & $\mathbf{3 1 . 7}$ \\
Lower costs & $\mathbf{1 7 . 1}$ & $\mathbf{1 3 . 0}$ \\
Better treatment & $\mathbf{1 4 . 1}$ & $\mathbf{1 1 . 1}$ \\
Random chance & $\mathbf{1 4 . 5}$ & $\mathbf{1 5 . 5}$ \\
More confidence (e.g. in quality) & $\mathbf{8 . 1}$ & $\mathbf{1 2 . 0}$ \\
Habit or custom & $\mathbf{7 . 3}$ & $\mathbf{6 . 8}$ \\
Has everything one could need & $\mathbf{3 . 4}$ & $\mathbf{5 . 4}$ \\
Needed a product & $\mathbf{3 . 2}$ & $\mathbf{2 . 0}$ \\
Only pharmacy available & $\mathbf{1 . 6}$ & $\mathbf{1 . 0}$ \\
Has good products & $\mathbf{1 . 0}$ & $\mathbf{0 . 7}$ \\
Hours of operation & $\mathbf{0 . 6}$ & $\mathbf{0 . 3}$ \\
First time client & $\mathbf{0 . 2}$ & $\mathbf{0 . 2}$ \\
Only one with the desired product & - & $\mathbf{0 . 4}$ \\
Other & - & $\mathbf{0 . 3}$ \\
\hline Total & $\mathbf{1 0 0}$ & $\mathbf{1 0 0}$ \\
\hline N $=$ & $\mathbf{6 1 9}$ & $\mathbf{8 3 2 3}$ \\
\hline
\end{tabular}

The reasons for attending a particular pharmacy could vary by how close to the pharmacy they live or work. In all, 63.5 percent of persons interviewed lived or worked near the pharmacy in which they were interviewed, while 36.5 percent came from outside the area. Specific reasons why the pharmacy was used, comparing those who lived or worked nearby with those who did not, are shown on Table 11. For 42.2 percent of those living or working nearby, pharmacy use was due to convenience for the buyer. For 35.4 percent of those coming from outside the area, use of the pharmacy was due to random chance. Seeking lower costs was the reason for 14.9 percent of people coming from outside the areas versus 11.9 percent of those who live nearby, suggesting that some people were specifically drawn in for economic reasons. People from outside the area were also attracted by the good treatment and the availability of most products. 
Other reasons were distributed more or less randomly by place of residence. These data suggest that the pharmacies that sell CEMOPLAF products are in desirable locations that are highly accessible to both local residents and outsiders.

Table 11: Reasons for Use, Comparing Purchasers Living or Working near Pharmacy with Those Who Don't

\begin{tabular}{|l|c|c|}
\hline \multirow{2}{*}{ Reasons for using pharmacy } & \multicolumn{2}{|c|}{ LIVE OR WORK NEAR THE } \\
\cline { 2 - 3 } & YES(\%) & NO (\%) \\
\hline Convenience & $\mathbf{4 2 . 2}$ & $\mathbf{1 3 . 0}$ \\
Random chance & $\mathbf{4 . 0}$ & $\mathbf{3 5 . 4}$ \\
Lower costs & $\mathbf{1 1 . 9}$ & $\mathbf{1 4 . 9}$ \\
Better treatment & $\mathbf{1 1 . 3}$ & $\mathbf{1 0 . 8}$ \\
More confidence (e.g. in quality) & $\mathbf{1 3 . 7}$ & $\mathbf{8 . 4}$ \\
Habit or custom & $\mathbf{7 . 6}$ & $\mathbf{5 . 6}$ \\
Has everything one could need & $\mathbf{4 . 7}$ & $\mathbf{6 . 1}$ \\
Has good products & $\mathbf{0 . 6}$ & $\mathbf{0 . 8}$ \\
Only pharmacy available & $\mathbf{0 . 9}$ & $\mathbf{1 . 4}$ \\
Needed a product & $\mathbf{2 . 2}$ & $\mathbf{1 . 9}$ \\
Only one with the desired product & $\mathbf{0 . 2}$ & $\mathbf{0 . 7}$ \\
Hours of operation & $\mathbf{0 . 3}$ & $\mathbf{0 . 4}$ \\
First time client & $\mathbf{0 . 1}$ & $\mathbf{0 . 5}$ \\
Other & $\mathbf{0 . 2}$ & $\mathbf{0 . 2}$ \\
\hline Total & $\mathbf{1 0 0}$ & $\mathbf{1 0 0}$ \\
\hline N $=$ & $\mathbf{5 6 7 9}$ & $\mathbf{3 2 6 3}$ \\
\hline
\end{tabular}

Table 12: Reasons Given for Using Pharmacy, by City

\begin{tabular}{|l|c|c|c|c|c|}
\hline \multirow{2}{*}{ Reasons for using pharmacy } & \multicolumn{5}{|c|}{ CITY IN ECUADOR } \\
\cline { 2 - 6 } & Quito (\%) & Guayaquil (\%) & Sto. Domingo (\%) & Riobamba (\%) & Ambato (\%) \\
\hline Convenience & $\mathbf{3 6 . 5}$ & $\mathbf{3 1 . 4}$ & $\mathbf{1 9 . 3}$ & $\mathbf{3 9 . 2}$ & $\mathbf{3 1 . 2}$ \\
Random chance & $\mathbf{1 0 . 9}$ & $\mathbf{2 2 . 0}$ & $\mathbf{9 . 5}$ & $\mathbf{1 8 . 4}$ & $\mathbf{2 2 . 4}$ \\
Lower costs & $\mathbf{8 . 0}$ & $\mathbf{1 5 . 0}$ & $\mathbf{2 3 . 1}$ & $\mathbf{8 . 1}$ & $\mathbf{6 . 5}$ \\
Better treatment & $\mathbf{7 . 5}$ & $\mathbf{1 0 . 4}$ & $\mathbf{2 3 . 4}$ & $\mathbf{6 . 3}$ & $\mathbf{3 . 8}$ \\
More confidence (e.g. in quality) & $\mathbf{1 0 . 0}$ & $\mathbf{1 0 . 9}$ & $\mathbf{1 3 . 9}$ & $\mathbf{7 . 0}$ & $\mathbf{2 5 . 8}$ \\
Habit or custom & $\mathbf{1 2 . 4}$ & $\mathbf{1 . 2}$ & $\mathbf{4 . 2}$ & $\mathbf{1 0 . 5}$ & $\mathbf{6 . 3}$ \\
Has everything one could need & $\mathbf{5 . 3}$ & $\mathbf{6 . 9}$ & $\mathbf{4 . 0}$ & $\mathbf{5 . 2}$ & $\mathbf{0 . 9}$ \\
Has good products & $\mathbf{0 . 8}$ & $\mathbf{0 . 3}$ & $\mathbf{0 . 5}$ & $\mathbf{1 . 7}$ & $\mathbf{1 . 2}$ \\
Only pharmacy available & $\mathbf{1 . 7}$ & $\mathbf{0 . 2}$ & $\mathbf{0 . 7}$ & $\mathbf{2 . 1}$ & $\mathbf{1 . 2}$ \\
Needed a product & $\mathbf{5 . 2}$ & $\mathbf{0 . 3}$ & $\mathbf{1 . 0}$ & $\mathbf{0 . 3}$ & $\mathbf{0 . 5}$ \\
Only one with desired product & $\mathbf{0 . 8}$ & $\mathbf{0 . 4}$ & $\mathbf{0 . 1}$ & - & - \\
Hours of operation & $\mathbf{0 . 6}$ & $\mathbf{0 . 1}$ & - & $\mathbf{1 . 0}$ & $\mathbf{0 . 3}$ \\
First time client & - & $\mathbf{0 . 7}$ & - & - & - \\
Other & $\mathbf{0 . 3}$ & $\mathbf{0 . 2}$ & $\mathbf{0 . 2}$ & $\mathbf{0 . 3}$ & - \\
\hline Total & $\mathbf{1 0 0}$ & $\mathbf{1 0 0}$ & $\mathbf{1 0 0}$ & $\mathbf{1 0 0}$ & $\mathbf{1 0 0}$ \\
\hline N $=$ & $\mathbf{2 9 9 3}$ & $\mathbf{2 6 7 5}$ & $\mathbf{1 7 4 6}$ & $\mathbf{9 4 2}$ & $\mathbf{5 8 6}$ \\
\hline
\end{tabular}


For all pharmacy users, the reasons given as most important for having utilized that pharmacy had some interesting variations by city of residence that reflect differences in consumer culture. Table 12 shows that convenience was the major reason for using a pharmacy in all cities except Santo Domingo, a tropical inland city at sea-level, where lower costs and better treatment were the most important reasons. In addition to Santo Domingans, Quiteños were less likely to use a pharmacy due to random chance as compared to other cities. Rather, Quiteños, as well as Riobambans, had more of a propensity than people in other cities to use a pharmacy from habit or custom. Ambato, a smaller-sized traditional town in the mountains, was the only one in which greater confidence in the pharmacy or its owners was one of the main reasons given for using the pharmacy in which they were interviewed.

\section{Products Sought but Not Found}

A total of $167(1.9 \%)$ of the 8,942 study subjects did not find a product for which they had gone to find at the pharmacy. The list of products sought but not found at the pharmacies are listed by type in Table 13, classified by whether or not the pharmacy client had also bought a CEMOPLAF product. The products most frequently not found were antibacterial/antimicrobial/antiviral medicines such as antibiotics, analgesics, anti-inflammatory medicines, vitamins, and cold remedies. These data suggest the types of products that CEMOPLAF could use to expand the range of their market, especially since these five types of products coincide with the non-CEMOPLAF products that were most frequently purchased, as was shown on Table 4.

\section{Table 13: Pharmaceutical Products Sought but not Found in Pharmacies by Study Population}

\begin{tabular}{|l|c|c|}
\hline \multirow{2}{*}{ Product not found } & \multicolumn{2}{|c|}{ SOURCE OF OTHER PURCHASES } \\
\cline { 2 - 3 } & CEMOPLAF $(\%)$ & OTHERS $(\%)$ \\
\hline Antibacterials, anti-microbials, antivirals & $\mathbf{2 5 . 0}(\mathbf{1})$ & $\mathbf{1 0 . 4}$ \\
Analgesics & - & $\mathbf{7 . 4}$ \\
Anti-inflamatories & - & $\mathbf{7 . 4}$ \\
Vitamins & - & $\mathbf{7 . 4}$ \\
Cold remedies & - & 4.9 \\
Antidepressants & - & $\mathbf{3 . 7}$ \\
Anti-diabetics & - & $\mathbf{3 . 7}$ \\
Other & $\mathbf{7 5 . 0}(\mathbf{3})$ & $\mathbf{5 5 . 1}$ \\
\hline Total & $\mathbf{1 0 0}$ & $\mathbf{1 0 0}$ \\
\hline $\mathrm{N}=$ & $\mathbf{4}$ & $\mathbf{1 6 3}$ \\
\hline
\end{tabular}

\section{Discussion and Recommendations}

In 1999, the CEMOPLAF project sold 21 contraceptive products and 22 other pharmaceutical products (some in various presentations such as capsules, syrups, and child and adult doses). Some of the products were purchased by CEMOPLAF from pharmaceutical companies (pregnancy tests, prescription drugs, etc.) and others were USAID donations (Lo-Femenal, 
DMPA, IUDs, condoms). The highest selling products were pills (300,000 per year), condoms (800,000 per year), injectable contraceptives (75,000 doses annually), and home pregnancy tests (50,000 tests per year). The list of CEMOPLAF products and sales figures for 1999 is found in the appendices.

The amounts of CEMOPLAF products reported as purchased in the current market survey are roughly proportional to the 1999 sales figures. This helps to confirm the validity of the random selection procedures used to draw the sample of pharmacies and pharmacy clientele.

A summary of market assessment findings and recommendations follow:

1. Data showing differences in socioeconomic characteristics of pharmacy clientele between the five study cities in educational attainment, age, gender, and partner status reflect the general socioeconomic and cultural environment of each city. It is a reminder that CEMOPLAF sales promotion strategies should take different approaches in different cities according to the socioeconomic profile of the local users.

2. The study showed few differences in socioeconomic characteristics between pharmacy clients who purchased CEMOPLAF products versus purchasers of non-CEMOPLAF products, except for those related to higher concentration of contraceptive purchasers among CEMOPLAF buyers. That is, CEMOPLAF purchasers were more frequently women of fertile age. However, when only contraceptive purchasers are considered, the study results suggest that, compared to non-CEMOPLAF contraceptive purchasers, CEMOPLAF buyers are generally from a lower level of educational attainment, and that a relatively important reason for them to purchase at the pharmacy was to get a lower price. Convenience and lower cost were the two major reasons why CEMOPLAF product buyers shopped at the pharmacy where they made a purchase. These findings suggest that CEMOPLAF should continue to use promotional strategies that target lower socioeconomic populations. At the same time, it is possible that a higher socioeconomic class of buyers could be targeted by special promotional efforts in order to further expand the market.

3. The non-CEMOPLAF products most frequently purchased were analgesics, antibacterials/antimicrobials/antivirals, anti-inflammatory drugs, vitamins, and cold remedies. These were also, not so coincidently, the items most frequently sought but not found. CEMOPLAF already sells selected products in these categories. Since there is a large demand for them, CEMOPLAF could move more strongly into these products to capture more of their market.

4. Information on whether a medicine was purchased with a physician's prescription is useful for monitoring how successful the CEMOPLAF program is in promoting specific pharmaceutical brands through private physicians.

5. The large proportion of persons coming from outside the immediate neighborhood of the study pharmacies (36.5\%) suggests that an expansion of pharmacies to new neighborhoods would capture additional clients who would be attracted to CEMOPLAF products by lower prices. 


\section{A. Recommendations for future market profile studies}

As a final conclusion of the present market assessment of the CEMOPLAF customer profile, we can say that the same methods and variables used for this study should definitely be utilized for on-going periodic monitoring of the CEMOPLAF social marketing program. The current study will serve as a baseline, and future efforts will show how customers are responding to marketing and pricing strategies employed by CEMOPLAF.

The following are suggestions for future market profile studies:

1. The questionnaire should include information on amount (i.e. number of doses) and price paid for each specific product purchased.

2. It is suggested that the questionnaire used for this study be redesigned to ensure that information is captured about each medicine purchased by each interviewee. For each medicine mentioned, questions should be asked about for whom is the medicine and if a prescription was used for its purchased.

3. The question regarding for whom the product is purchased could use just three categories of possible responses: self, spouse or partner, or other. This would shorten the time needed to fill out the questionnaire, and would especially simplify the data input and data analysis.

4. Incentives or gifts should not be given to pharmacy survey respondents due to the risk of altering the normal purchasing habits of the population.

5. The sample size should be increased if possible to allow a larger number of CEMOPLAF product buyers to fall into the sample so that analyses of their characteristics would have more statistical power, and more disaggregated analyses could be carried out. 


\section{STUDY III: QUALITY OF CARE ISSUES IN DELIVERY OF INJECTABLE AND ORAL CONTRACEPTIVES AND A PREGNANCY TEST IN ECUADOREAN PHARMACIES}

Authors: Federico R. León, James R. Foreit, Rosa Monge, Ana María Buller, Teresa de Vargas, Ernesto Pinto, \& María del Rosario Naranjo

\section{Introduction}

Reproductive health programs face a major challenge: to provide a greater variety of products and services to a rapidly increasing number of users. CEMOPLAF is a non-governmental organization (NGO) that operates a variety of reproductive health programs throughout Ecuador, including 21 reproductive health clinical centers and a social marketing program. Today, social marketing is the largest producer of CEMOPLAF's revenue, accounting for approximately 36 percent of gross income (approximately $\$ 67,000$ per month). The program sells contraceptive and reproductive health products to pharmacies, physicians, and other distributors and nontraditional outlets including liquor stores, hotels, motels and brothels. The program sells 34 purchased products (pregnancy tests, prescription drugs, etc.) and USAID donated products (LoFemenal, DMPA, IUDs, condoms). In terms of sales, the most important are pills $(234,000$ cycles per year), condoms (800,000 packages of three per year), injectable contraceptives (100,000 doses per year), and home pregnancy tests (40,000 tests per year).

CEMOPLAF has conducted evaluation and operations research (OR) to improve its social marketing program as an effective channel for delivering family planning and reproductive health services (e.g., Bratt et al., 1994, 1995, 1998). This research has been concerned with the economic aspects of the program. Another aspect of the program in need of research is the quality of the client-pharmacist interaction. CEMOPLAF is concerned that social marketing clients purchasing hormonal methods receive adequate information and management of methodrelated side effects. CEMOPLAF clinical service norms require that users of hormonal methods receive counseling at acceptance and follow up, but no official policy governs quality of information that pharmacists should give to clients.

This study was designed to obtain inputs for the design of interventions to enhance pharmacist information-giving behavior. The study objective was to collect observations on the clientpharmacist interaction during the provision of oral and injectable contraceptives and pregnancy tests to identify strengths and weaknesses.

\section{Methods}

CEMOPLAF medical staff decided the minimum information that pharmacists should be able to provide customers using DMPA (Depo-Provera), combined oral contraceptives, and a pregnancy test. On this basis, research staff constructed three Service Tests, one per product, to assess the extent to which pharmacists give information to customers. A Service Test consists of a set of instructions to perform as a simulated client (customer profile) and register behavioral observations on a checklist. The customer profile contains a set of instructions concerning what 
the simulated client must say or ask the pharmacist. The checklist includes expected pharmacist behaviors whose presence must be verified by the simulated customer. For contraceptives, these included talking about contraindications, giving instructions for correct use, and side effects of the method.

Female physicians were selected to conduct the Service Tests. In the case of the injectable contraceptive, the customer profile referred to a healthy 30 year-old woman who had a 1.5 yearold child, was presently menstruating, was a user of the calendar rhythm method, and wanted to start using DMPA (Depo-Provera). She was trained to visit pharmacies as a simulated client and ask, "Can you please give me an injectable contraceptive?" If the pharmacist offered several brands, she was expected to ask, "Which one would you recommend?" and choose one (DepoProvera, unless it was not offered). If the pharmacist did not spontaneously provide usage instructions, she would ask, "How should I use it?" and then, "What should I do if I forget to apply it in the expected date?" if the pharmacist did not provide this instruction. The simulated client was trained to use the checklist and register her observations as soon as she left the pharmacy.

The client profile for combined oral contraceptives referred to a healthy woman between 25 and 30 years who had a 1.5 year-old child, was presently menstruating, was a user of the calendar rhythm method, and wanted to start taking pills. She was trained to visit pharmacies as a simulated client and ask, "Can you please give me a package of contraceptive pills?" If the pharmacist offered several brands, she was trained to ask, "Which one would you recommend?" and choose one. If the pharmacist did not spontaneously provide usage instructions, she would ask, "How should I take them?" and then, "What should I do if I forget to take them every day?" if the pharmacist did not provide this instruction.

Finally, the client profile for the pregnancy test referred to a young woman (17 to 30 years old) that suspected she was pregnant and wanted to rule out this possibility using a pregnancy test. She was trained to visit pharmacies as a simulated client and ask, "Can you please give me a pregnancy test?" If the pharmacist offered several brands, she was expected to ask, "Which one would you recommend?" and choose one. If the pharmacist did not spontaneously provide usage instructions, she would ask, "How should I use it?" As in the two previous cases, the simulated client was trained to use the checklist and register her observations as soon as she left the pharmacy.

The population of the study included all the pharmacies that were clients of CEMOPLAF in five Ecuadorean cities. Stratified random sampling was used to choose 15 pharmacies in Guayaquil and 15 in Quito (five each from northern, central, and southern city areas). In Ambato and Riobamba, 5 pharmacies were randomly chosen in each city. Ten were chosen in Santo Domingo. One simulated client visited the 50 pharmacies requesting DMPA, another requesting pills, and the third requesting a pregnancy test. 


\section{RESULTS}

A. Injectable

Injectable contraceptives were available in the 50 pharmacies. Figure 1 describes the observed flow of client-pharmacist interactions. Of the 50 pharmacists involved, 41 offered the simulated client the option to choose the brand. Only 9 pharmacists offered just one brand to the client. (The study did not ascertain whether this was due to the lack of alternative brands in stock or preferences of the pharmacists.) Regardless of number of brands offered, 28 pharmacists spontaneously offered information about the injectable contraceptive(s) and 22 failed to do so. When the simulated client asked for information she received it in all cases.

Table 1 presents specific information per item of the checklist taking into account the phase of the client-pharmacist interaction. Phase A mainly encompasses the pharmacist's spontaneous initiatives; the only request from the client in this phase concerned the guidance to choose one of the brands. In Phase B, the pharmacist was responding to the client's specific request for usage instructions. In Phase $\mathrm{C}$, the pharmacist responded to the client's request for advice concerning what to do if she forgot to apply the injection in the due date.

About one-third of the total number of pharmacists spontaneously stated prices and asked the client whether she was a new user. These figures increased to almost one-half in the second phase of the client-pharmacist interaction. At the end of the third phase, information concerning prices was given to the client in more than three fourths of the cases. The only question asked to screen the client for contraindications was whether she was menstruating (to rule out pregnancy). Twenty-two pharmacists failed to ask this question.

About one-third of the pharmacists spontaneously informed the client that the injection is applied the first time when the woman is menstruating and then every three months (Phase A). When the client asked for usage instructions, 90 percent or more of the pharmacists referred to the presence of menstruation for the first injection and the 3-month interval between injections. Only when the client asked specifically what to do if she forgot an injection did some of the pharmacists address the issue and the ensuing risk of pregnancy. Pharmacists did not talk about the inserts within the product packages. Information given to the client about side effects was practically nonexistent. 
Figure 1. Injectable: Distribution of Cases in the Client - Pharmacist Interaction Dynamics

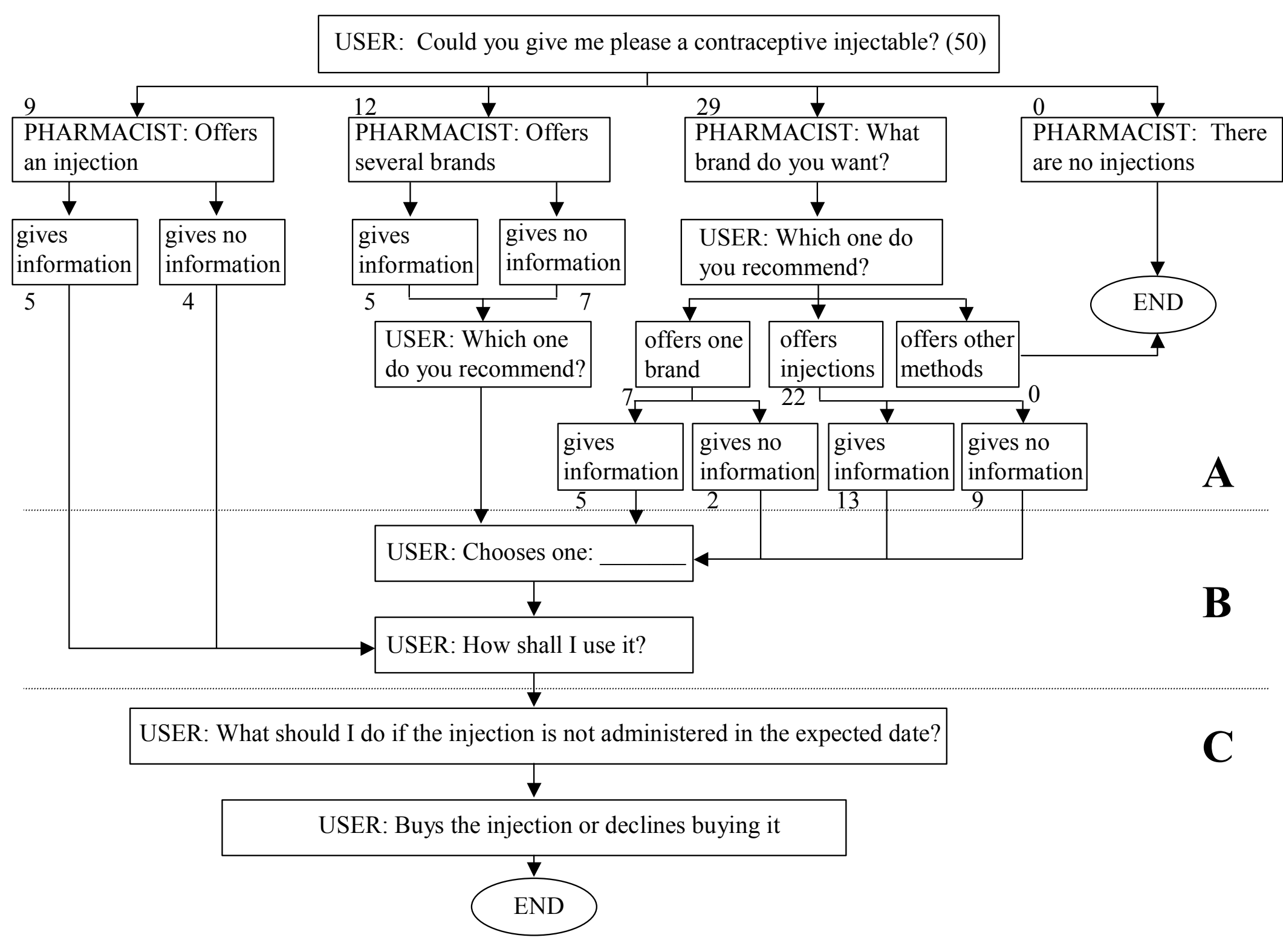




\begin{tabular}{|c|c|c|c|c|}
\hline \multicolumn{5}{|c|}{$\begin{array}{l}\text { Table 1. Injectable: Information given/asked by pharmacist in each phase of } \\
\text { interaction with client, } \quad n=50\end{array}$} \\
\hline \multicolumn{2}{|c|}{ Items } & $\mathbf{A}$ & B & $\mathbf{C}$ \\
\hline 1 & Price & 16 & 4 & 22 \\
\hline \multirow[t]{2}{*}{2} & Is this your first time? & 20 & 9 & 0 \\
\hline & \multicolumn{4}{|l|}{ Contraindications } \\
\hline 3 & Check it with your physician & 2 & 0 & 0 \\
\hline 4 & Pregnancy & 1 & 0 & 0 \\
\hline 5 & Are you menstruating? & 14 & 14 & 0 \\
\hline 6 & Non-menstrual vaginal bleeding & 1 & 2 & 0 \\
\hline 7 & Hard formations in the breast or breast cancer & 0 & 0 & 0 \\
\hline \multicolumn{5}{|c|}{ Usage Instructions: } \\
\hline 8 & Injection administered every three months & 19 & 27 & 0 \\
\hline 9 & First injection administered during menstruation & 12 & 33 & 0 \\
\hline 10 & Forgetfulness & 1 & 4 & 12 \\
\hline 11 & Risk of pregnancy & 1 & 3 & 24 \\
\hline 12 & Reading instructions & 0 & 0 & 0 \\
\hline \multicolumn{5}{|c|}{ Side Effects } \\
\hline 13 & Menstruation may be irregular or spotting may be observed & 3 & 1 & 0 \\
\hline 14 & There may be lack of menstruation & 0 & 0 & 0 \\
\hline 15 & Temporary infertility after discontinuation & 0 & 0 & 0 \\
\hline
\end{tabular}

\section{B. Pills}

Pills were available in the 49 pharmacies of the sample (there was 1 missing case). Figure 2 describes the observed flow of client-pharmacist interactions. Of the 49 pharmacists involved, 40 offered the simulated client the option to choose the brand. Only 9 pharmacists offered just one brand to the client, and this study did not ascertain whether this was due to the lack of alternative brands in stock or preferences of the pharmacists. Regardless of number of brands offered, 16 pharmacists spontaneously offered information about the pills and 31 failed to do so. When the simulated client asked for information, she received it in all cases. There were also two pharmacists that offered other methods.

Table 2 presents specific information per item of the checklist taking into account the phase of the client-pharmacist interaction. Phase A mainly encompasses the pharmacist's spontaneous initiatives; the only request from the client in this phase concerned the guidance to choose one of the brands. In Phase B, the pharmacist was responding to the client's specific request for usage instructions. In Phase $\mathrm{C}$, the pharmacist responded to the client's request for advice concerning what to do if she forgets to take the pill everyday. 
Figure 2 Pill: Distribution of Cases in the Client - Pharmacist Interaction Dynamics

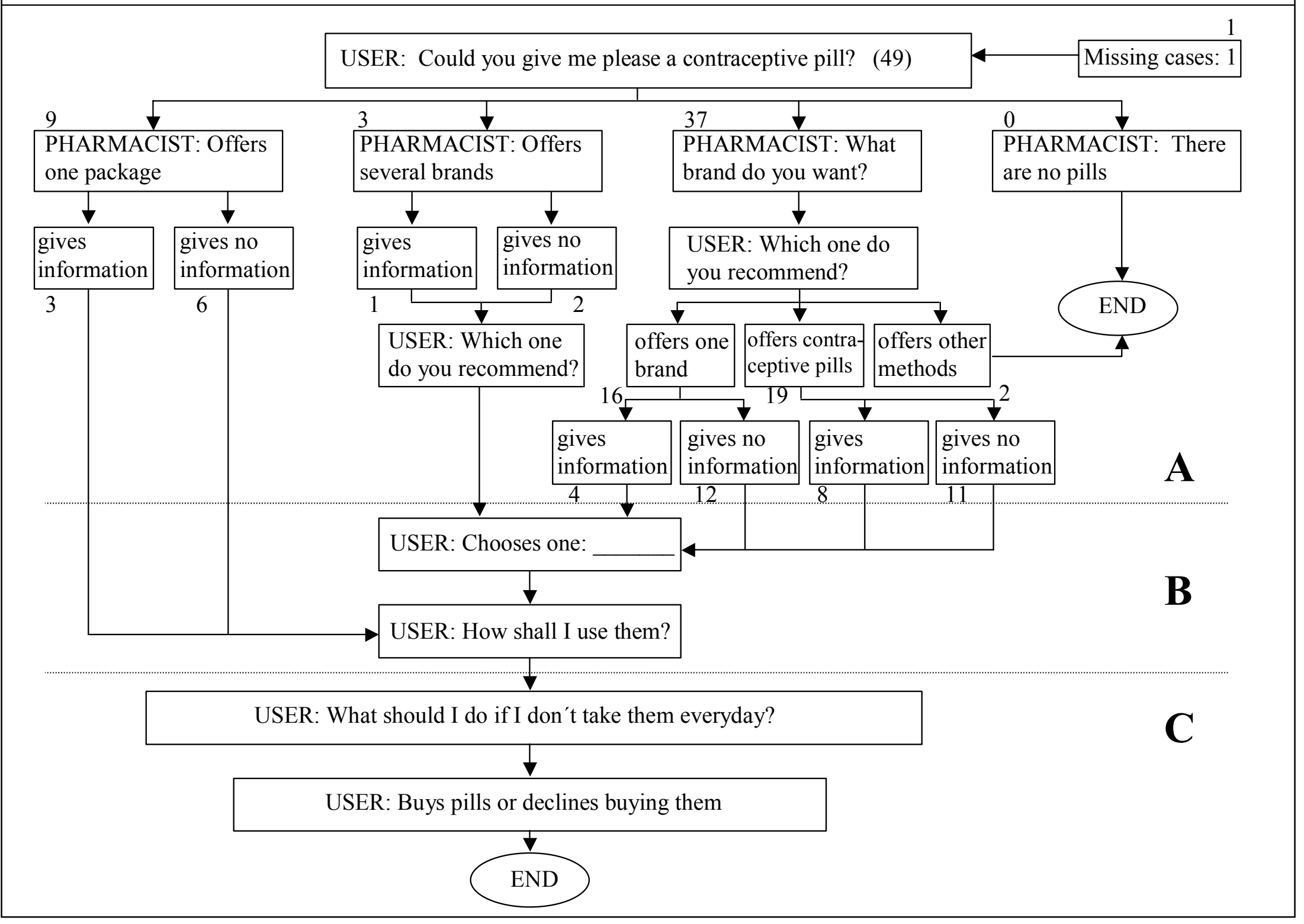




\begin{tabular}{|c|c|c|c|c|}
\hline \multirow{2}{*}{\multicolumn{2}{|c|}{ Items }} & \multicolumn{3}{|c|}{ Phase } \\
\hline & & $\mathbf{A}$ & B & $\mathbf{C}$ \\
\hline 1 & Price & 24 & 3 & 21 \\
\hline \multirow[t]{2}{*}{2} & Is this your first time? & 12 & 9 & 0 \\
\hline & \multicolumn{4}{|l|}{ Contraindications } \\
\hline 3 & Check it with your physician & 2 & 1 & 0 \\
\hline 4 & Are you menstruating? & 8 & 7 & 0 \\
\hline 5 & Pregnancy & 0 & 1 & 0 \\
\hline 6 & Breastfeeding & 0 & 1 & 0 \\
\hline 7 & Non-menstrual vaginal bleeding & 0 & 0 & 0 \\
\hline 8 & Hard formations in the breast or breast cancer & 1 & 0 & 0 \\
\hline 9 & Cardiovascular diseases & 1 & 0 & 0 \\
\hline 10 & Liver diseases & 1 & 1 & 0 \\
\hline \multicolumn{5}{|c|}{ Usage Instructions: } \\
\hline 11 & Every day & 6 & 39 & 1 \\
\hline 12 & Use of package & 4 & 25 & 2 \\
\hline 13 & Forgetfulness & 3 & 3 & 25 \\
\hline 14 & Risk of pregnancy & 0 & 2 & 21 \\
\hline 15 & Restart & 1 & 1 & 5 \\
\hline 16 & Reading instructions & 0 & 1 & 0 \\
\hline \multicolumn{5}{|c|}{ Side Effects } \\
\hline 17 & Headache & 0 & 1 & 0 \\
\hline 18 & Sickness & 0 & 0 & 0 \\
\hline 19 & Nervousness & 0 & 0 & 0 \\
\hline
\end{tabular}

As shown by Table 2, half of all pharmacists stated prices and a quarter asked the client whether she was a new user, both in the first phase. Information about contraindications or usage instructions was very low in this phase; the most frequently reported items ("are you menstruating?" and "pills must be taken every day") were mentioned by only 15 percent of pharmacists.

When the client asked for usage instructions (Phase B), 80 percent of the pharmacists said that pills must be taken every day and about 50 percent referred to the correct use of the package. Only when the client asked specifically what to do if she forgot to take a pill, did some of the pharmacists address the issue and the ensuing risk of pregnancy. Pharmacists did not talk about restarting pills or about inserts within the product package. Information given to the client about side effects was practically nonexistent in the three phases. 


\section{Pregnancy Test}

There were three missing cases. Pregnancy tests were sold in 46 pharmacies. Figure 3 shows the flow of client-pharmacist interactions. Of the 46 pharmacies, 29 offered the simulated client the option to choose the pregnancy test brand while 17 pharmacists offered one brand to the client. (The study did not ascertain whether this was due to the lack of alternative brands in stock or preferences of the pharmacists.) Regardless of number of brands offered, it can be observed that the great majority of pharmacists (45) did not spontaneously offer information about the pregnancy test. When the simulated client asked for information, she received it in all cases.

In this Service Test, Phases A and C mainly encompasses the pharmacist's spontaneous initiatives, while Phase B encompasses the pharmacist's answers to the client's question about usage instructions (see Figure 3).

Most pharmacists stated prices in the first phase and about 1/3 in the second phase. Only two pharmacists gave instructions spontaneously (Phase A), whereas half of the cases gave instructions or told the simulated client to read them in the second phase, that is, after the simulated client specifically asked how to use the product (Table 3). Questions about the probable date the pregnancy, or the suggestion to check with a physician were nonexistent. 


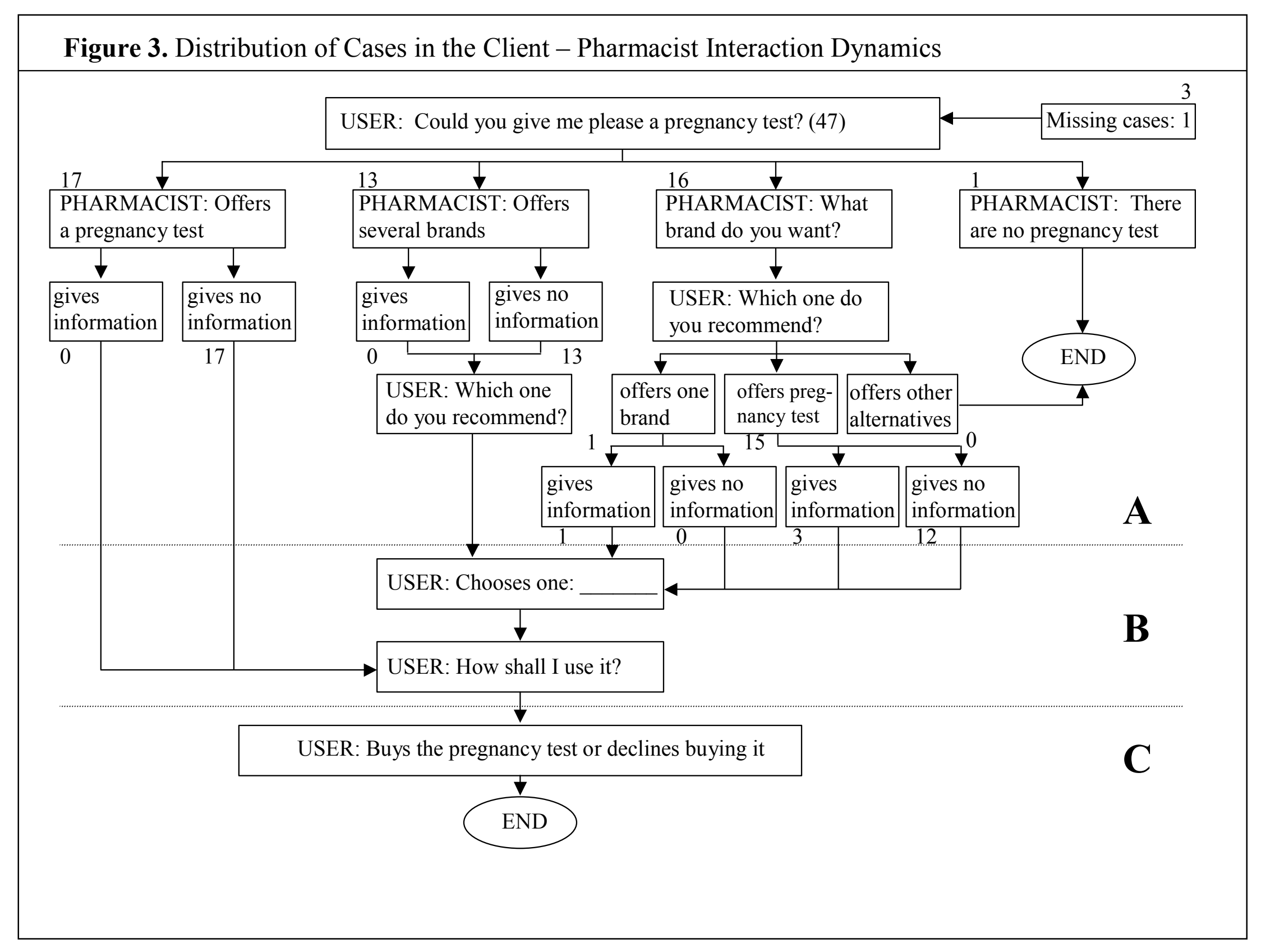




\begin{tabular}{|c|c|c|c|c|}
\hline \multirow{3}{*}{\multicolumn{2}{|c|}{ Items }} & \multirow{2}{*}{\multicolumn{3}{|c|}{ Phase }} \\
\hline & & & & \\
\hline & & A & $\mathbf{B}$ & $\mathbf{C}$ \\
\hline 1 & Price & 27 & 17 & 3 \\
\hline 2 & How long has your menstrual period been missing & 0 & 0 & 0 \\
\hline \multirow[t]{2}{*}{3} & Check it with your physician & 0 & 0 & 0 \\
\hline & Usage Instructions (depending on the test) & & & \\
\hline 4 & Gives instructions & 2 & 24 & 0 \\
\hline 5 & Reads instructions & 0 & 24 & 0 \\
\hline
\end{tabular}

\section{Discussion}

This study revealed that pharmacists behave very much like clinical providers of family planning methods: they tend to formulate questions concerning the menstrual status of the client and give her usage instructions but little or no information about side effects and contraindications (León et al., 1999).

On the other hand, the study showed that the pharmacist's asking standard questions and giving usage instructions are increased when the client formulates specific questions. This suggests an intervention to enhance provider's information-giving behavior: stimulating the client to formulate questions, which can be done by placing posters with appropriate messages within the pharmacies.

The same intervention could be used to change pharmacist information-giving behavior concerning contraindications and side effects. In this case, the posters would have to specifically tell the client to ask for contraindications and side effects.

\section{References}

Bratt, J. H., J. R. Foreit, T. De Vargas, \& E. Pinto (1994) “"'Improving financial sustainability through income generation: An approach for estimating profitability of ultrasound in an Ecuadorian family planning agency.” Research Triangle Park, NC: Family Health International. (Unpublished.)

Bratt, J. H., J. R. Foreit, T. De Vargas, \& E. Pinto (1995) “An assessment of client 'ability to pay' for reproductive health services provided by an Ecuadorian family planning agency." Research Triangle Park, NC: Family Health International. (Unpublished.)

Bratt, J. H., J. R. Foreit, \& T. De Vargas (1995) “Three strategies to promote sustainability of CEMOPLAF clinics in Ecuador.” Studies in Family Planning 29, 1: 58-68.

León, F. R., G. Vallenas, R. Monge, M. R. Gárate, A. Ríos, A. Espinoza, A .Calderón, I. García, \& A. Zumarán (1999) "Monitoring family planning providers' compliance with the quality-of-care norms of Peru's Ministry of Health.” Final Report of FRONTIERS project. Lima: Population Council. 


\section{CONFERENCE: SUSTAINABILITY AND SOCIAL MISSION: SHARING LESSONS FROM RESEARCH AND PRACTICE}

Author: Kristina Lantis

\section{Introduction}

The conference, Sustainability and Social Mission: Sharing Lessons from Research and Practice, was held May 16 - 18, 2001 in Quito, Ecuador. Over 80 attendees representing more than 40 organizations and 12 countries met to discuss how to improve financial sustainability through the use of business practices while continuing to fulfill their social mission of serving the poor. The conference was sponsored by CEMOPLAF of Quito, Ecuador, and by two United States Agency for International Development (USAID) funded projects, Frontiers in Reproductive Health and Commercial Market Strategies (CMS).

\section{Attendees}

More than 80 individuals registered to attend the conference. They represented over 40 family planning organizations, research organizations, pharmaceutical companies, and donors. A complete list of registrants can be found in the appendix.

\section{Conference Objectives}

The conference objectives were to:

- Share sustainability research and lessons learned;

- Share experiences of NGOs that have attempted to improve the sustainability of programs while maintaining their commitment to social mission; and

- Provide NGOs and companies that market reproductive health products the opportunity to explore the possibility of commercial agreements.

\section{Agenda}

The conference consisted of three full days of panel presentations, question and answer sessions, roundtable sessions and open discussions. Presentations were given in both Spanish and English with simultaneous translation. A copy of the agenda can be found in the appendix.

\section{A. Day One}

The conference began with a welcome and statement of objectives from representatives of the three sponsoring organizations: Teresa de Vargas, CEMOPLAF; Alvaro Monroy, CMS; and Ricardo Vernon, FRONTIERS. 
The first panel, Sustainability vs. Social Mission: What do programs need to do?, discussed the definitions of both social mission and sustainability, their compatibility and the challenges NGOs and the commercial sector will face with regard to sustainability and social mission.

Following a discussion of Panel 1, four discussion groups were formed for participants to discuss donor expectations, barriers to commercial growth, definition of social mission and private sources of funding.

The second panel discussed research findings from Ecuador, Guatemala, Honduras, and El Salvador on the impact of sustainability activities on program utilization and client profile. The panel was followed by a 45-minute open discussion of agency experiences with the impact of price increases on utilization.

\section{B. Day Two}

Two panels took place in the morning of the second day. The first discussed various market research tools including market research surveys, willingness to pay surveys, psycho-behavioral market segmentation and focus groups and other qualitative techniques. The second panel, Calculating and Using Cost Information, discussed calculating costs, price setting, profitability analysis and cross-subsidies. Both panels were followed by half-hour discussion sessions.

Panelists in the afternoon discussed marketing strategies for reproductive health services such as: in-reach and missed opportunities, quality, diversification, the addition of commercial marketing and selling to the commercial sector.

Representatives from CMS, FRONTIERS and The Futures Group International (TFGI) provided participants with assistance in obtaining research tools and discussed opportunities for research collaboration at a round table session.

\section{Day Three}

The final day of the conference began with a presentation on alternative financing mechanisms. Representatives from various commercial sector companies, including CPR, Drogueria Inti, General Electric Health Systems and Schering, discussed "What can the commercial sector offer NGOs to make them more sustainable?" in Panel 6.

The final two round tables of the conference discussed the experiences of Latin American agencies with products and services, both profitable and non-profitable.

The conference closed with comments and conclusions from Alvaro Monroy, CMS and Teresa de Vargas, CEMOPLAF. 


\section{Sustainability Snapshot}

Organizations attending the conference were asked to complete a form concerning their budgetstructure (percent donor vs. percent self-generated) and future of donor funding.

- $11 / 20$ organizations indicated they were more than 50 percent self-sustainable (more than 50 percent of their budget was self-generated).

- Of those $>50$ percent self-sustainable organizations, 2/11 said their donor funding would remain stable and 9/11 indicated that their donor funding would be decreasing.

- 9/20 organizations were less than 50 percent self-sustainable (more than 50 percent of their budget came from donor funds), of these organizations 5 predicted decreasing donor funding, 3 predicted their donor funding would remain stable and one predicted its donor funding would increase.

- $19 / 20$ organizations indicated their donor funding would either remain stable (5) or would decrease (14). The one organization that indicated its donor funding would increase is also 0 percent self-sustainable.

- When funding structure information was combined for all 20 organizations and averaged, 45 percent of the budget was donor funded and 55 percent was self-generated.

- $2 / 20$ organizations indicated that 100 percent of their budget came from donor funds. If these two organizations are not included, the average budget structure for the remaining 18 is: 39 percent donor funded and 61 percent self-generated.

\section{Conference Evaluation}

Results of the conference evaluation are available in the appendix. More than eighty percent of the participants felt the conference met its objectives and found the ideas useful and practical. 


\section{APPENDICES}

\section{Appendix 1 - Allocation Decisions and Other Assumptions}

1. Allocation of Joint Expenses in the Quito Region

Staff Meetings - if the expense was less than S/.300,000, it was allocated to the Quito sales agents; otherwise it was allocated to all sales agents.

Courses and Seminars, Promotional Material, Promotion Activities - these expenses were allocated equally to all sales agents.

Travel and Per diem - these expenses were allocated equally to non-Quito sales agents.

Vehicle Maintenance - these expenses were allocated equally to Quito sales agents.

2. Assumptions underlying Capital Costs

We assumed that each sales agent had access to a computer for record-keeping (invoices, accounts receivable and payable, etc.), and a basic suite of furniture including a desk, a chair and a filing cabinet. The SM program also owns a vehicle that is used exclusively in the Quito region.

The table below presents information used to calculate annualized cost for capital items.

\begin{tabular}{|l|c|c|c|}
\hline Item & Purchase Price & Useful Life & Discount Rate \\
\hline Computer/printer & 1,000 & 5 years & $10 \%$ \\
\hline Office Furniture & 200 & 10 years & $10 \%$ \\
\hline Vehicle - Vitara & 11,063 & 10 years & $10 \%$ \\
\hline
\end{tabular}

3. Calculation of Equivalent Rent

An estimate of average rental cost per square meter was needed to compute a monthly "equivalent rent" for the clinics that CEMOPLAF owns. This estimate was generated using the data in the following table.

\begin{tabular}{|l|c|c|c|}
\hline Clinic & Monthly Rent (S/.) & Clinic Area $\left.\mathbf{~ M}^{\mathbf{2}}\right)$ & Cost per $\mathbf{M}^{\mathbf{2}}$ \\
\hline Tulcan & $1,000,000$ & 120 & 8,333 \\
\hline Ibarra & 900,000 & 200 & 4,500 \\
\hline Quininde & 530,000 & 130 & 4,077 \\
\hline Quito - COP & $1,200,000$ & 147 & 8,163 \\
\hline Average & & & 6,268 \\
\hline
\end{tabular}




\section{Appendix 2}

CEMOPLAF Social Marketing Program Sales During 1999

Prepared by Dr. Mónica C. De Sánchez

\begin{tabular}{|c|c|c|c|c|c|}
\hline PRODUCT & $\begin{array}{c}\text { TOTAL } \\
\text { NUMBER }\end{array}$ & $\%$ & PRODUCT & $\begin{array}{c}\text { TOTAL } \\
\text { NUMBER }\end{array}$ & $\%$ \\
\hline IUD's & & & OTHER PRODUCTS cont. & & \\
\hline Tcu 380 A ( units) & 64746 & 9.96 & Bacterol 20 capsules & 1588 & 0.24 \\
\hline \multirow[t]{2}{*}{ Spirals } & 1 & 0.00 & Bacterol forte $\mathrm{x} 10$ capsules & 3724 & 0.57 \\
\hline & & & Bacterol susp. & 3500 & 0.54 \\
\hline $\begin{array}{c}\text { ORAL } \\
\text { CONTRACEPTIVES }\end{array}$ & & & Doxifen cream & 2590 & 0.40 \\
\hline Marvelon (dose) & 2807 & 0.43 & Doxifen óvulos & 2822 & 0.43 \\
\hline Microgynon (box x 3) & 19161 & 2.95 & Doxifen Dual & 299 & 0.05 \\
\hline Microgynon CD ( box x 3) & 19499 & 3.00 & Bacticel Simple & 88 & 0.01 \\
\hline Lo Femenal (dose) & 226568 & 34.85 & Bacticel Forte & 149 & 0.02 \\
\hline Exluton (dose) & 13018 & 2.00 & Bacticel Susp & 189 & 0.03 \\
\hline Nordette (dose) & 3454 & $\mathbf{0 . 5 3}$ & Invigan & 1118 & 0.17 \\
\hline Trinordiol (dose) & 1591 & 0.24 & Compofen & 2886 & 0.44 \\
\hline Minulet (dose) & 6057 & 0.93 & Mobic 7.5 & 1458 & 0.22 \\
\hline Gynera (dose) & 3906 & 0.60 & Mobic 15 & 998 & 0.15 \\
\hline Gynera CD & 3034 & 0.47 & Mobic syringes & 760 & 0.12 \\
\hline Mercilon & 1717 & 0.26 & Bisolvon & 9304 & 1.43 \\
\hline Femiane & 969 & 0.15 & Buscapina simple & 1132 & 0.17 \\
\hline \multirow[t]{2}{*}{ Harmonet } & 426 & 0.07 & Buscapina (tablets) & 6918 & 1.06 \\
\hline & & & Buscapina (syringe) & 5883 & 0.90 \\
\hline INJECTABLES & & & Buscapina plus (capsules) & 4586 & 0.71 \\
\hline Depo provera & 3787 & 0.58 & Kiddi & 3219 & 0.50 \\
\hline Mesigyna & 28234 & 4.34 & Pharmaton & 2403 & 0.37 \\
\hline \multirow[t]{2}{*}{ Topasel } & 43113 & 6.63 & Pharmaton complex & 2996 & 0.46 \\
\hline & & & Cutamycon cream & 1263 & 0.19 \\
\hline BARRIER & & & Cutamycon Vag. Tab. & 493 & 0.08 \\
\hline Panther (units) & 37417 & 5.76 & Rotopar tab. & 3766 & 0.58 \\
\hline Protektor (box x 3) & 23282 & 3.58 & Rotopar susp. & 3607 & 0.55 \\
\hline \multirow[t]{2}{*}{ Conceptrol (units) } & & 0.00 & Trigentax cream & 8260 & 1.27 \\
\hline & & & Tinidameb & 897 & 0.14 \\
\hline OTHER PRODUCTS & & & Premarin 0.625 & 1316 & 0.20 \\
\hline Detector $\mathrm{x} 25$ & 13263 & 2.04 & Premarin cream & 549 & 0.08 \\
\hline Detector x 10 & 14896 & 2.29 & Materna & 5140 & 0.79 \\
\hline Detector Gold & 3938 & 0.61 & Dulcolax & 1853 & 0.29 \\
\hline Pregcolor & 165 & 0.03 & Neogripal x 12 & 868 & 0.13 \\
\hline Pregcolor Premium & 17783 & 2.74 & Neogripal x 60 & 270 & 0.04 \\
\hline Clamox óvulos & 3823 & 0.59 & Neogripal syrup & 1069 & 0.16 \\
\hline Clámox cream & 2042 & 0.31 & Neogripal drops & 1437 & 0.22 \\
\hline Funzal & 2005 & 0.31 & TOTAL & 650100 & 100.00 \\
\hline
\end{tabular}




\section{Appendix 3}

\section{CONFERENCE AGENDA: SUSTAINABILITY AND SOCIAL MISSION}

\begin{tabular}{|c|c|c|}
\hline \multicolumn{3}{|c|}{ Day 1 Agenda: Wednesday, May 16, 2001} \\
\hline 8:00 a.m. - 9:00 a.m. & Registration & \\
\hline 9:00 a.m. - 9:30 a.m. & $\begin{array}{l}\text { Welcome and } \\
\text { Conference Objectives }\end{array}$ & $\begin{array}{l}\text { Teresa de Vargas, CEMOPLAF } \\
\text { Alvaro Monroy, CMS } \\
\text { Ricardo Vernon, FRONTIERS }\end{array}$ \\
\hline 9:30 a.m. $-10: 30$ a.m. & $\begin{array}{l}\text { Panel 1: Sustainability vs. Social } \\
\text { Mission: What Do Programs Need } \\
\text { to Do? }\end{array}$ & $\begin{array}{l}\text { Moderator: Ney Costa, } \\
\text { BEMFAM }\end{array}$ \\
\hline $9: 30-9: 45$ & Definition of sustainability & Alvaro Monroy, CMS \\
\hline $9: 45-10: 00$ & $\begin{array}{l}\text { Are sustainability and social } \\
\text { mission compatible? }\end{array}$ & Guy Stalworthy, PSI \\
\hline $10: 00-10: 15$ & Private sector social mission & Santiago Cordova, CELSAM \\
\hline $10: 15-10: 30$ & $\begin{array}{l}\text { NGO and commercial sector } \\
\text { challenges }\end{array}$ & Karen Foreit, TFGI \\
\hline 10:30 a.m. $-11: 00$ a.m. & Discussion & \\
\hline 11:00 a.m. $-11: 15$ a.m. & Coffee Break & \\
\hline 11:15 a.m. $-12: 15$ p.m. & $\begin{array}{l}\text { Discussion Groups } \\
\text { How much do we expect from } \\
\text { donors and how much must we } \\
\text { raise in non-donor funds to } \\
\text { survive? } \\
\text { Barriers to commercial sector } \\
\text { growth. } \\
\text { How do LAC NGOs define social } \\
\text { mission? } \\
\text { Private donors and foundations as } \\
\text { a source of funding. }\end{array}$ & $\begin{array}{l}\text { José Luis Corral, CELSAM } \\
\text { Catalina Uribe, PROFAMILIA- } \\
\text { CO } \\
\text { Maricela Durá, MEXFAM }\end{array}$ \\
\hline
\end{tabular}




\begin{tabular}{|c|c|c|}
\hline 12:15 p.m. $-1: 15$ p.m. & Discussion Group Presentations & $\begin{array}{l}\text { Moderator: Jim Foreit, } \\
\text { FRONTIERS }\end{array}$ \\
\hline 1:15 p.m. $-2: 30$ p.m. & Lunch & \\
\hline 2:30 p.m. $-3: 15$ p.m. & $\begin{array}{l}\text { Panel 2: Research Findings on the } \\
\text { Impact of Sustainability Activities } \\
\text { on Program Utilization and Client } \\
\text { Profile. }\end{array}$ & Moderator: Karen Foreit, TFGI \\
\hline $2: 30-2: 45$ & $\begin{array}{l}\text { Socio-economic profiles of NGO } \\
\text { clients in Ecuador, Guatemala, } \\
\text { Honduras and El Salvador. }\end{array}$ & John Bratt, FHI \\
\hline $2: 45-3: 00$ & $\begin{array}{l}\text { Impact of price increases on client } \\
\text { profiles. }\end{array}$ & Zonia Aguilar, APROFAM \\
\hline $3: 00-3: 15$ & $\begin{array}{l}\text { Impact of sustainability activities } \\
\text { on demand for services and client } \\
\text { profile in CEMOPLAF }\end{array}$ & Ernesto Pinto, CEMOPLAF \\
\hline 3:15 p.m. $-4: 00$ p.m. & $\begin{array}{l}\text { Open Floor Discussion of Agency } \\
\text { Experiences with the Impact of } \\
\text { Price Increases on Utilization }\end{array}$ & $\begin{array}{l}\text { Moderator: Teresa de Vargas, } \\
\text { CEMOPLAF }\end{array}$ \\
\hline
\end{tabular}

\begin{tabular}{|c|l|l|}
\hline \multicolumn{2}{|l|}{ Day 2 Agenda: Thursday, May 17, 2001 } \\
\hline 9:00 a.m. - 10:00 a.m. & Panel 3: Market Research Tools & Moderator: John Bratt, FHI \\
9:00 - 9:15 & Market research survey & José Alvarez, CHSP \\
9:15 - 9:30 & Willingness to Pay (WTP) surveys & Jim Foreit, FRONTIERS \\
9:30 - 9:45 & Psycho-behavioral segmentation \\
9:45 - 10:00 & $\begin{array}{l}\text { Focus groups and other qualitative } \\
\text { techniques }\end{array}$ & $\begin{array}{l}\text { Ratha Loganathan, CMS } \\
\text { Martha Mérida, PROSALUD. }\end{array}$ \\
\hline 10:00 a.m. - 10:30 a.m. & Discussion & \\
\hline 10:30 a.m. - 10:45 a.m. & Coffee Break & $\begin{array}{l}\text { Moderator: Ney Costa, } \\
\text { BEMFAM }\end{array}$ \\
\hline 10:45 a.m. - 11:45 a.m. & $\begin{array}{l}\text { Panel 4: Calculating and Using } \\
\text { Cost Information }\end{array}$ & \\
\hline
\end{tabular}




\begin{tabular}{|c|c|c|}
\hline 10:45-11:00 & Calculating Costs & Jésus Servin, FEMAP \\
\hline $11: 00-11: 15$ & $\begin{array}{l}\text { Price setting using cost and other } \\
\text { criteria. }\end{array}$ & $\begin{array}{l}\text { Catalina Uribe, PROFAMILIA- } \\
\text { Columbia }\end{array}$ \\
\hline $11: 15-11: 30$ & $\begin{array}{l}\text { Profitability analysis of } \\
\text { CEMOPLAF marketing program }\end{array}$ & Rosario Naranjo, CEMOPLAF \\
\hline $11: 30-11: 45$ & When do cross-subsidies work? & Julia Walsh, BIG. \\
\hline 11:45 a.m. $-12: 15$ p.m. & Discussion & \\
\hline 12:15 p.m. $-1: 30$ p.m. & Lunch & \\
\hline 1:30 p.m. $-2: 45$ p.m. & $\begin{array}{l}\text { Panel 5: Marketing Strategies for } \\
\text { Reproductive Health Services }\end{array}$ & $\begin{array}{l}\text { Moderator: Carlos Morlacchi, } \\
\text { ASHONPLAFA }\end{array}$ \\
\hline $1: 30-1: 45$ & $\begin{array}{l}\text { In-reach and missed opportunities } \\
\text { to provide more services. }\end{array}$ & Ricardo Vernon, FRONTIERS \\
\hline $1: 45-2: 00$ & Quality as a marketing strategy. & $\begin{array}{l}\text { Miriam Becerra/Agustín Cuesta, } \\
\text { APROFE }\end{array}$ \\
\hline $2: 00-2: 15$ & $\begin{array}{l}\text { Diversification beyond } \\
\text { reproductive health }\end{array}$ & Brian Mitchell, BIG \\
\hline $2: 15-2: 30$ & $\begin{array}{l}\text { Adding commercial marketing to } \\
\text { NGO activities. }\end{array}$ & Ney Costa, BEMFAM \\
\hline $2: 30-2: 45$ & Selling to the commercial sector. & $\begin{array}{l}\text { Magali Caram, PROFAMILIA- } \\
\text { Dominican Republic. }\end{array}$ \\
\hline 2:45 p.m. $-3: 15$ p.m. & Discussion & \\
\hline 3:15 p.m. $-4: 15$ p.m. & $\begin{array}{l}\text { Round Tables: Getting Technical } \\
\text { Assistance for Research. } \\
\text { Representatives of CMS, } \\
\text { FRONTIERS and TFGI will } \\
\text { provide help to participants in } \\
\text { obtaining research tools and will } \\
\text { discuss possibilities for research } \\
\text { collaboration with donors and } \\
\text { service delivery agencies. }\end{array}$ & $\begin{array}{l}\text { José Alvarez, CHSP } \\
\text { Ratha Loganathan, CMS } \\
\text { Jim Foreit/Ricardo Vernon, } \\
\text { FRONTIERS } \\
\text { John Bratt, FHI } \\
\text { Karen Foreit, TFGI }\end{array}$ \\
\hline
\end{tabular}




\begin{tabular}{|c|c|c|}
\hline \multicolumn{3}{|c|}{ Day 3 Agenda: Friday, May 18, 2001} \\
\hline 8:45 a.m. $-9: 15$ a.m. & Alternative Financing Mechanisms & $\begin{array}{l}\text { Carlos Carrazana, Summa } \\
\text { Foundation }\end{array}$ \\
\hline 9:15 a.m. $-9: 45$ a.m. & Discussion & \\
\hline 9:45 a.m. $-12: 15$ p.m. & $\begin{array}{l}\text { Panel 6: What Can the } \\
\text { Commercial Sector Offer NGOs to } \\
\text { Make Them More Sustainable? }\end{array}$ & \\
\hline $9: 45-10: 15$ & CPR & Michael Kesserling \\
\hline $10: 15-10: 45$ & Drogueria Inti & Cristian Schelling \\
\hline $10: 45-11: 15$ & General Electric Health Systems & Fernando Antúnes \\
\hline $11: 15-11: 45$ & Hindustani Latex & Alan Forney and Ayappan M \\
\hline $11: 45-12: 15$ & Schering & Marco Egas \\
\hline 12:15 p.m. $-1: 15$ p.m. & $\begin{array}{l}\text { Round Table: Profitable and Non- } \\
\text { profitable Products: The } \\
\text { Experiences of LAC Agencies } \\
\text { ADS } \\
\text { BEMFAM } \\
\text { CEMOPLAF } \\
\text { MEXFAM }\end{array}$ & $\begin{array}{l}\text { Moderator: Carlos Morlacchi, } \\
\text { ASHONPLAFA } \\
\text { Jorge Hernández } \\
\text { Ney Costa } \\
\text { Jenny Vásquez } \\
\text { Maricela Durá }\end{array}$ \\
\hline 1:15 p.m. $-1: 35$ p.m. & Discussion & \\
\hline 1:35 p.m. $-2: 35$ p.m. & Lunch & \\
\hline 2:35 p.m. $-3: 35$ p.m. & $\begin{array}{l}\text { Round Table: Profitable and Non- } \\
\text { profitable Services: The } \\
\text { Experiences of LAC Agencies } \\
\text { APROFE } \\
\text { BEMFAM } \\
\text { CEMOPLAF } \\
\text { MEXFAM } \\
\text { PROSALUD }\end{array}$ & $\begin{array}{l}\text { Moderator: Daniel Aspilcueta, } \\
\text { INPPARES } \\
\text { Pablo Marangoni } \\
\text { Ney Costa } \\
\text { Teresa de Vargas } \\
\text { Maricela Durá } \\
\text { Martha Mérida }\end{array}$ \\
\hline 3:35 p.m. $-3: 55$ p.m. & Discussion & \\
\hline 3:55 p.m. $-4: 25$ p.m. & Conclusions and Closing & $\begin{array}{l}\text { Alvaro Monroy, CMS } \\
\text { Teresa de Vargas, CEMOPLAF }\end{array}$ \\
\hline
\end{tabular}




\section{Appendix 4}

\section{ATTENDEE LIST: SUSTAINABILITY AND SOCIAL MISSION CONFERENCE}

\begin{tabular}{|c|c|c|}
\hline Name & Institution & E-mail \\
\hline Jorge Hernández & ADS & jorgeh@ads.org.sv \\
\hline Cossette Ramírez & ADS & mercadeo@ads.org.sv \\
\hline Zonia Aguilar & APROFAM & zaguilar@aprofam.org.gt \\
\hline Hugo Icú & ASECSA & \\
\hline Miguel Cap & RENACIMIENTO & \\
\hline Carlos Morlacchi & ASHONPLAFA & cmorlacchi@ashonplafa.com \\
\hline Ricardo Reyes & ASHONPLAFA & rreyes@ashonplafa.com \\
\hline Ney Costa & BEMFAM & info@bemfam.org.br \\
\hline Marcelo Mendonca & BEMFAM & info@bemfam.org.br \\
\hline José Luis Corral & CELSAM & \\
\hline Marcela Durá & MEXFAM & developm@mexfam.org.mx \\
\hline Josefina Martínez & MEXFAM & imartínez@mexfam.org.mx \\
\hline Enrique Suárez & FEMAP & femap@,infolink.net \\
\hline Jesús Servin & FEMAP & femap@,infolink.net \\
\hline José Alvarez Blas & CHSP & \\
\hline Daniel Aspilcueta & INPPARES & DASPILCU@INPPARES.org.pe \\
\hline Olenka Zapata & INPPARES & \\
\hline Gabriel Ojeda & PROFAMILIA Colombia & gojeda@profamilia.org.co \\
\hline Catalina Uribe & PROFAMILIA Colombia & curibe@profamilia.org.co \\
\hline Magali Caram & PROFAMILIA Rep. Dominicana & profamilia@codetel.net.do \\
\hline Bienvenida Bobadilla & PROFAMILIA Rep. Dominicana & profamilia@,codetel.net.do \\
\hline Martha Mérida & PROSALUD & \\
\hline Jack Antelo & CIES & jantelo@caoba.entelnet.bo \\
\hline Ramiro Mayorga & PROFAMILIA & \\
\hline Maria de Moya & CMS & \\
\hline Miguel Vela López & MAXSALUD & direjec@maxsalud.org.pe \\
\hline Julio Zabala & APROPO & \\
\hline Elba Mercado & USAID & emercado@usaid.gov \\
\hline Rosa Rita Alvarez & MUDE & mude@centennialrd.net \\
\hline Ramón Portes & ADOPLAFAM & adoplafa@tricom.net \\
\hline Kirk Leach & INTERNATIONAL EYE FOUND. & \\
\hline Ing. Abastoflor & INTERNATIONAL EYE FOUND. & \\
\hline Cristian Schilling & INTI & \\
\hline John Bratt & FHI & jbratt@,fhi.org \\
\hline Jim Foreit & FRONTIERS & jforeit@pcdc.org \\
\hline Kris Lantis & FRONTIERS & klantis@pcdc.org \\
\hline Ricardo Vernon & FRONTIERS & rvernon@popcouncil.org.mx \\
\hline Guy Stalworthy & PSI & guys@psieurope.org.uk \\
\hline Karen Foreit & TFGI & k.foreit@,tfgi.com \\
\hline Alvaro Monroy & CMS & amonroy@cmsproject.com \\
\hline Kell Wolfe & CMS & \\
\hline Ratha Logarthanan & CMS & \\
\hline Carlos Carrazana & SUMMA FOUNDATION & \\
\hline Alan Forney & HINDUSTAN LATEX & \\
\hline Ayyappan M. & HINDUSTAN LATEX & \\
\hline Marco Egas & SCHERING & \\
\hline
\end{tabular}




\begin{tabular}{|l|l|l|}
\hline \multicolumn{1}{|c|}{ Name } & \multicolumn{1}{|c|}{ Institution } & \\
\hline Santiago Cordova & SCHERING & \\
\hline Cristopher Price & FPIA & \\
\hline Jesus Mendoza & FPIA & \\
\hline Julio Beingolea & VECINOS MUNDIALES & \\
\hline Isabel Stout & Catalyst Consortium Project & msemmelbeck@rhcatalyst.org \\
\hline Marie France Semmelbeck & Catalyst Consortium Project & \\
\hline Isabel Morales & Endowment Fund for Sustainab. & \\
\hline Luis Hernández & Endowment Fund for sustainab & \\
\hline Marguerite Farrell & USAID, LAC Bureau & \\
\hline Milo Schaub & CPR & \\
\hline Michael Kesserling & CPR & jwalsh@,socrates.berkeley.edu \\
\hline Julia Walsh & BIG & gordon@,are.berkeley.edu \\
\hline Deanna Gordon & BIG & mitch4brian@,hotmail.com \\
\hline Brian Mitchell & BIG & \\
\hline Nicole Buono & USAID Washington & lluchsinger@, usaid.gov \\
\hline Lisa Luchsinger & USAID Washington & \\
\hline Victoria Fuentes & UNFPA & cemoplaf@,uio.satnet.net \\
\hline Ernesto Pinto & CEMOPLAF & cemoplaf@,uio.satnet.net \\
\hline Teresa de Vargas & CEMOPLAF & cemoplaf@,uio.satnet.net \\
\hline Carmen Acosta de Pozo & CEMOPLAF & cemoplaf@,uio.satnet.net \\
\hline Rosario Naranjo & CEMOPLAF & \\
\hline Jenny Vasques & CEMOPLAF & \\
\hline Aida Haro & CEMOPLAF & \\
\hline Esmeralda Garcia & COLEGIO DE OBSTETRICES PICHINCHA & \\
\hline Miriam Becerra & APROFE & \\
\hline Agustín Cuesta & APROFE & \\
\hline Paolo Marangoni & APROFE & \\
\hline Pablo Palacios & JOHNS HOPKINS UNIVERSITY & \\
\hline Ivan Palacios & CARE & \\
\hline Nelson Oviedo & CEPAR & \\
\hline Margarita Quevedo & CORPORACION KIMIRINA & \\
\hline Orlando Batallas & COF & \\
\hline Carolyn Benbow-Ross & UNFPA & \\
\hline Aída Lafebre & USAID & \\
\hline Roberto Goyes & CHRISTIAN CH.ec \\
\hline & & \\
\hline
\end{tabular}




\section{Appendix 5}

\section{EVALUATION: SUSTAINABILITY AND SOCIAL MISSION CONFERENCE}

TOTAL DE PARTICIPANTES EVALUADOS: 47

\begin{tabular}{|c|c|c|c|c|c|c|}
\hline I. EVALUACIÓN A LA CONFERENCIA & $\begin{array}{c}5 \\
\text { Excelente }\end{array}$ & $\begin{array}{c}4 \\
\text { Muy Bueno }\end{array}$ & $\begin{array}{c}3 \\
\text { Bueno }\end{array}$ & $\begin{array}{c}2 \\
\text { Regular }\end{array}$ & $\begin{array}{c}1 \\
\text { Malo }\end{array}$ & $\begin{array}{c}5 / 4 \\
\text { Excelente/ } \\
\text { Muy Bueno } \\
\end{array}$ \\
\hline 1. Alcance de los objetivos & 18 & 24 & 5 & & & $89 \%$ \\
\hline 2. Contenido de la Conferencia & 21 & 21 & 5 & & & $89 \%$ \\
\hline 3. Estructura y secuencia & 21 & 19 & 5 & 2 & & $85 \%$ \\
\hline 4. Profundidad & 11 & 27 & 9 & & & $81 \%$ \\
\hline 5. Utilidad y aplicación de los temas & 16 & 25 & 5 & 1 & & $87 \%$ \\
\hline \multicolumn{7}{|l|}{ II. EVALUACIÓN A LOS FACILITADOROS } \\
\hline 1. Dominaron el tema & 22 & 19 & 6 & & & $87 \%$ \\
\hline 2. Capacidad didáctica & 18 & 18 & 11 & & & $77 \%$ \\
\hline $\begin{array}{l}\text { 3. Forma en que propiciaron la } \\
\text { participación del grupo }\end{array}$ & 20 & 15 & 11 & 1 & & $74 \%$ \\
\hline $\begin{array}{l}\text { 4. Respondieron a las preguntas de los } \\
\text { participantes }\end{array}$ & 19 & 21 & 7 & & & $85 \%$ \\
\hline \multicolumn{7}{|l|}{ III. EVALUACIÓN DEL PARTICIPANTE } \\
\hline 1. Adquirí habilidad y conocimientos & 16 & 25 & 5 & 1 & & $87 \%$ \\
\hline 2. Me integré al grupo & 17 & 22 & 6 & 2 & & $83 \%$ \\
\hline 3. Puse atención y participé & 18 & 26 & 3 & & & $93 \%$ \\
\hline 4. Demostré interés y esfuerzo & 22 & 23 & 2 & & & $96 \%$ \\
\hline \multicolumn{7}{|l|}{ IV. EVALUACIÓN DE LOGÍSTICA } \\
\hline 1. Calidad del material didáctico & 26 & 18 & 3 & & & $94 \%$ \\
\hline 2. Condiciones físicas y ambientales & 42 & 3 & 1 & 1 & & $96 \%$ \\
\hline 3. Duración de la conferencia & 34 & 9 & 2 & & & $91 \%$ \\
\hline 4. Horario de la conferencia & 32 & 13 & 2 & & & $96 \%$ \\
\hline 5. Apoyo logístico & 33 & 13 & 1 & & & $98 \%$ \\
\hline
\end{tabular}

\section{SUGERENCIAS:}

- Felicitación - Gracias!

- Ninguna - Felicitaciones

- Excelente conferencia

- Felicitaciones a CEMOPLAF

- Continúen adelante

- Gracias por la hospitalidad

- En algunos temas sugiero mayor profundidad

- Menos presentaciones y más grupos de discusiones como el primer día

- Volver a organizar otra conferencia con más participación del grupo

- En otra conferencia pedir la participación directa de las ONGs que aportan con ayuda económica

- Publicar los resultados

- Thank you for the excellent translation! Thank you!!
- Favor de repartir las presentaciones antes de las ponencias pues permite hacer anotaciones coherentes y oportunas. ¡Gracias por tanta amabilidad al personal de apoyo!

- Dar secuencia para nuevas reuniones para intercambio de experiencias

- Quizá muy apretada la agenda

- Agradecimiento por el evento tan importante en organización, contenido y objetivos

- Hacerla en 2 años, profundizar en la reducción de costos. Excelente conferencia

- Felicitaciones y realizar la próxima conferencia CEMOPLAF did an outstanding job with organization, I only wish there had been more direct contact before and concerning logistics. 


\section{Appendix 6}

\section{LIST OF PRESENTATIONS: SUSTAINABILITY AND SOCIAL MISSION CONFERENCE}

\section{TITLE}

Sustainabilty

La Sustentabilidad y la Misión Social

Sector Privado Misión Social

Sustentabilidad y Misión Social: Desafíos para las ONGs y el Sector Comercial

Como Definen las ONG LAC la Misión Social?

Donantes y Fundaciones Privadas como una Fuente de Financiamiento

Perfile Socioeconómicos de los Clientes ONG en Ecuador, El Salador, Guatemala y Honduras

Cuánto Necesitamos Incrementar los Precios para Cambiar el Perfil de las Usuarias Impacto de Actividades de Sustentabilidad sobre Demand de Servicios y Perfil de Usuarios de Planificación Familiar en CEMOPLAF

Using Simple Survey Techniques to Set Prices for Social Products and Services

Herramienta de Investigación de Mercado: Segmentación Psicografica

Herramienta de Investigación de Mercado: Una Experiencia de PROSALUD

Análisis de Costos

A Profitability Analysis of the CEMOPLAF Social Marketing Program

When do cross-subsidies work?

\section{PRESENTER, ORGANIZATION}

Alvaro Monroy, CMS

Guy Stalworthy, PSI/Europe

Santiago Córdova, CELSAM

Karen Foreit, TFGI

Catalina Uribe, PROFAMILIA-Columbia

Maricela Durá, MEXFAM

John Bratt, FRONTIERS/FHI

Zonia Aguilar, APROFAM

Ernesto Pinto, CEMOPLAF

Jim Foreit, FRONTIERS

Ratha Loganathan, CMS

Martha Mérida, PROSALUD

Jesús Servín, FEMAP

Rosario Naranjo, CEMOPLAF

Julia Walsh, BIG 
Estrategías y efectos de disminuir las oportunidades perdids para prestar servicios de salud reproductivo

Calidad con una estrategia de mercadeo

Adding CM to NGO Activities: BEMFAM expertise

Diversity beyond Reproductive Health

Selling to the Commercial Sector

Accessing Credit and The Summa foundation

How can FPAs earn money out of the condom business in order to finance other social activities?

Productos y Servicios Rentables y no

Rentables in ASHONPLAFA

Productos y Servicios Rentables y no

Rentables

Productos y Servicios Rentables y no Rentables: La experiencia de CEMOPLAF

Productos y Servicios Rentables y no Rentables
Ricardo Vernon, FRONTIERS

Mirriam Becerra \& Agustín Cuesta, APROFE

Marcelo Mendonça, BEMFAM

Deanna Gordon \& Brian Mitchell, BIG

Magali Caram, PROFAMILIA-Dominican

Republic

Carlos A. Carranzana, The SUMMA

Foundation

Michael Kesserling, CPR

Carlos Morlacchi, ASHONPLAFA

Ney Costa, BEMFAM

Teresa de Vargas \& Jenny Vásquez, CEMOPLAF

Paolo Marangoni, APROFE 